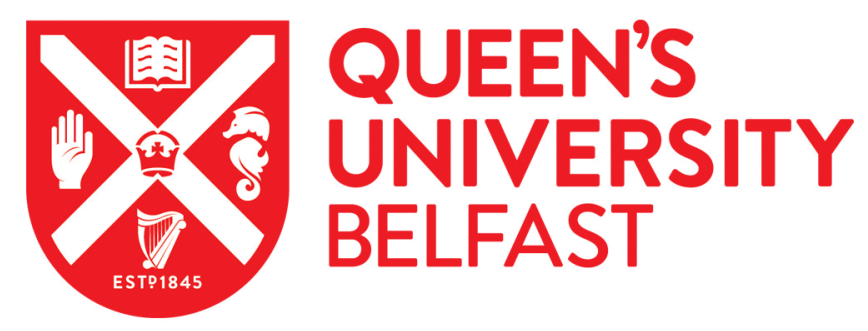

\title{
50,000 -years of vegetation and climate change in the southern Namib Desert, Pella, South Africa
}

\author{
Lim, S., Chevalier, M., Chase, B. M., \& Reimer, P. J. (2016). 50,000-years of vegetation and climate change in \\ the southern Namib Desert, Pella, South Africa. Palaeogeography, Palaeoclimatology, Palaeoecology, 197-209. \\ https://doi.org/10.1016/j.palaeo.2016.03.001
}

\section{Published in:}

Palaeogeography, Palaeoclimatology, Palaeoecology

\section{Document Version:}

Peer reviewed version

Queen's University Belfast - Research Portal:

Link to publication record in Queen's University Belfast Research Portal

\section{Publisher rights}

(c) Elsevier B. V. 2016. This manuscript version is made available under the CC-BY-NC-ND 4.0

licensehttp://creativecommons.org/licenses/by-nc-nd/4.0/,which permits distribution and reproduction for non-commercial purposes, provided the author and source are cited.

\section{General rights}

Copyright for the publications made accessible via the Queen's University Belfast Research Portal is retained by the author(s) and / or other copyright owners and it is a condition of accessing these publications that users recognise and abide by the legal requirements associated with these rights.

Take down policy

The Research Portal is Queen's institutional repository that provides access to Queen's research output. Every effort has been made to ensure that content in the Research Portal does not infringe any person's rights, or applicable UK laws. If you discover content in the Research Portal that you believe breaches copyright or violates any law, please contact openaccess@qub.ac.uk. 


\section{Accepted Manuscript}

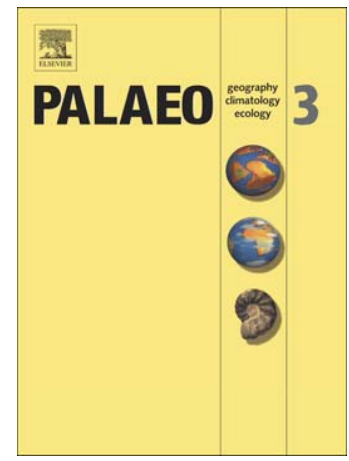

50,000-years of vegetation and climate change in the Southern Namib Desert, Pella, South Africa

Sophak Lim, Brian M. Chase, Manuel Chevalier, Paula J. Reimer

PII: S0031-0182(16)00161-9

DOI: doi: 10.1016/j.palaeo.2016.03.001

Reference: $\quad$ PALAEO 7734

To appear in: $\quad$ Palaeogeography, Palaeoclimatology, Palaeoecology

Received date: 21 October 2015

Revised date: $\quad 29$ February 2016

Accepted date: 1 March 2016

Please cite this article as: Lim, Sophak, Chase, Brian M., Chevalier, Manuel, Reimer, Paula J., 50,000-years of vegetation and climate change in the Southern Namib Desert, Pella, South Africa, Palaeogeography, Palaeoclimatology, Palaeoecology (2016), doi: 10.1016/j.palaeo.2016.03.001

This is a PDF file of an unedited manuscript that has been accepted for publication. As a service to our customers we are providing this early version of the manuscript. The manuscript will undergo copyediting, typesetting, and review of the resulting proof before it is published in its final form. Please note that during the production process errors may be discovered which could affect the content, and all legal disclaimers that apply to the journal pertain. 


\section{0,000 -years of vegetation and climate change in the}

\section{southern Namib Desert, Pella, South Africa}

Sophak Lim ${ }^{1 *}$, Brian M. Chase ${ }^{1}$, Manuel Chevalier ${ }^{1}$, Paula J. Reimer ${ }^{2}$

${ }^{1}$ Centre National de la Recherche Scientifique, UMR 5554, Institut des Sciences de l'Evolution de Montpellier, Université de Montpellier, Bat.22, CC061, Place Eugène Bataillon, 34095 Montpellier, cedex5, France

${ }^{2}$ School of Geography, Archaeology and Palaeoecology, Queen's University Belfast, Belfast, BT7 1NN, Northern Ireland, UK

*Corresponding author:

Institut des Sciences de l'Evolution de Montpellier (UMR 5554)

Université Montpellier 2, Bat.22 cc061

Place Eugène Bataillon

34095 Montpellier cedex 5

France

Phone: +33(0)4 67143925

e-mail: sophak.lim@univ-montp2.fr 


\section{KEYWORDS}

South Africa

Namib Desert

late Quaternary

rock hyrax middens

pollen

climate reconstruction

\section{HIGHLIGHTS}

- First continuous pollen record from southern Namib Desert spanning last $50 \mathrm{kyr}$.

- Last glacial period characterised by increased water availability relative to Holocene.

- Changes in potential evapotranspiration identified as important driver of humidity variability.

- Expansion of Desert Biome with increased Holocene temperatures.

- Consistently low Restionaceae pollen abundance indicates no significant expansion of Fynbos Biome during last 50 kyr. 


\section{ABSTRACT}

This paper presents the first continuous pollen record from the southern Namib Desert spanning the last 50,000 years. Obtained from rock hyrax middens found near the town of Pella, South Africa, these data are used to reconstruct vegetation change and quantitative estimates of temperature and aridity. Results indicate that the last glacial period was characterised by increased water availability at the site relative to the Holocene. Changes in temperature and potential evapotranspiration appear to have played a significant role in determining the hydrologic balance. The record can be considered in two sections: 1) the last glacial period, when low temperatures favoured the development of more mesic Nama-Karoo vegetation at the site, with periods of increased humidity concurrent with increased coastal upwelling, both responding to lower global/regional temperatures; and 2) the Holocene, during which time high temperatures and potential evapotranspiration resulted in increased aridity and an expansion of the Desert Biome. During this latter period, increases in upwelling intensity created drier conditions at the site.

Considered in the context of discussions of forcing mechanisms of regional climate change and environmental dynamics, the results from Pella stand in clear contrast with many inferences of terrestrial environmental change derived from regional marine records. Observations of a strong precessional signal and interpretations of increased humidity during phases of high local summer insolation in the marine records are not consistent with the data from Pella. Similarly, while high percentages of Restionaceae pollen has been observed in marine sediments during the last glacial period, they do not exceed $1 \%$ of the assemblage from Pella, indicating that no significant expansion of the Fynbos Biome has occurred during the last 50,000 years. These findings pose interesting questions regarding the nature of environmental change in southwestern Africa, and the significance of the diverse records that have been obtained from the region. 


\section{INTRODUCTION}

Palaeoenvironmental evidence, and particularly palynological data, from the Namib Desert region are notably scarce (cf. Chase and Meadows, 2007; Lancaster, 2002), and as a result very little is known about long-term climate and vegetation dynamics surrounding the hyperarid core of southwestern Africa. The arid environment has precluded the preservation of organic material, and most palaeoenvironmental records have been obtained from a diversity of geomorphic features such as dune sediments (Bateman et al., 2003; Blümel et al., 1998; Bristow et al., 2007; Chase and Thomas, 2006; Chase and Thomas, 2007; Eitel et al., 2002; Stokes et al., 1997; Stone and Thomas, 2008; Telfer, 2007; Thomas et al., 1998; Thomas et al., 1997), fluvial deposits (Blumel et al., 2000; Bourke et al., 2003; Eitel et al., 2002; Eitel and Zöller, 1996; Heine, 2004; Heine and Heine, 2002; Heine and Völkel, 2009; Lancaster, 2002; Srivastava et al., 2006; Stone et al., 2010; Vogel, 1982) and fragmentary lacustrine records (Cooke and Heine, 1979; Deacon and Lancaster, 1988; Heine, 1978, 1982; Lancaster, 1979, 1984; Lancaster, 1986; Lancaster and Teller, 1988; Teller and Lancaster, 1985; Teller and Lancaster, 1986; Teller et al., 1990; Ward, 1984). Many of these, while being potentially valuable indicators of landscape dynamics (Thomas, 2013), are of debatable palaeoclimatic significance (Chase, 2009; Chase and Brewer, 2009; Lancaster, 2002; Stone et al., 2010; Thomas and Burrough, 2012), and a coherent environmental context for their development remains to be established. In terms of palaeoecological records, while some Holocene age pollen records have been recovered from western Namibia, they are generally restricted to the mid- to latest Holocene (Gil-Romera et al., 2006; Gil-Romera et al., 2007; Scott, 1996; Scott et al., 1991), with only records from the Brandberg (Scott et al., 2004) providing snapshots of glacial-age vegetation in the Namib Desert.

This lack of terrestrial records has led to a reliance on records obtained from marine cores (cf. Chase and Meadows, 2007). While these sequences contain long, continuous 
records of terrestrial sediments (Gingele, 1996; Pichevin et al., 2005; Stuut et al., 2002; Weldeab et al., 2013), pollen (Shi and Dupont, 1997; Shi et al., 1998, 2000; Shi et al., 2001), charcoal (Daniau et al., 2013) and biomarkers (Collins et al., 2014; Collins et al., 2011; Rommerskirchen et al., 2003) the intense atmospheric and oceanic circulation systems dominating the Southeast Atlantic basin - particularly along the southwest African margin and the potential for significant aeolian and fluvial sediment contributions, have raised questions regarding the taphonomy, and thus significance, of the records obtained (cf. Chase and Meadows, 2007; Scott et al., 2004).

Despite the conflicts presented by these records and their interpretation, the regional dataset seems to generally indicate: 1) more humid conditions in the Namib during the last glacial period, particularly during marine isotope stage (MIS) 4 (71-59 ka) and during late MIS 3 and early MIS 2, from $\sim 35-24 \mathrm{ka}$, and 2) relatively drier conditions during the Holocene (synthesised in Chase and Meadows, 2007). The mechanisms driving the differences in glacial and interglacial climates remain unclear. While Chase and Meadows (2007) suggested that the prevalence of southwest African sites indicating increased humidity during the last glacial period may support prevailing conceptual models relating wetter glacial conditions to equatorward shifts in the westerly storm track (e.g. van Zinderen Bakker, 1976), it has also been suggested that more extensive Northern Hemisphere ice sheets would have resulted in a southward displacement of the African rainbelt (cf. the Intertropical Convergence Zone (ITCZ)), bringing more tropical rain to the region during the summer (Butzer, 1984; Butzer et al., 1978; Lancaster, 1979; Lewis et al., 2010). Quantifications of summer precipitation amounts in eastern South Africa (Chevalier and Chase, 2015; Truc et al., 2013) suggest that while some evidence exists to indicate increased tropical precipitation during the last glacial period (Schefuß et al., 2011; Thomas et al., 2009; Wang et al., 2013), this was restricted, at least in the east, to a narrow belt south of Lake Malawi, and that any zone of enhanced tropical rainfall was likely more restricted than some 
general circulation model (GCM) simulations suggest (cf. Lewis et al., 2010). A further consideration is the role of temperature on the regional hydrologic budget. Regardless of changes in the position or intensity of the regions' dominant moisture-bearing systems, indications are that temperatures in southern Africa were as much as $5^{\circ} \mathrm{C}$ to $6^{\circ} \mathrm{C}$ lower during the last glacial period (Chevalier and Chase, 2015; Kulongoski and Hilton, 2004; Stute and Talma, 1997; Stute and Talma, 1998; Talma and Vogel, 1992; Truc et al., 2013). This would have significantly reduced potential evapotranspiration (PET), and may have thus strongly influenced records derived from proxies sensitive to evaporation and water availability rather than purely rainfall amount (Chevalier and Chase, in press).

Here we present: 1) the first continuous pollen records from the southern Namib Desert and South Africa's Desert Biome spanning the last 50,000 years, and 2) quantified reconstructions of changes in aridity and mean annual temperature based on these data. The pollen records were obtained from two sections of a rock hyrax midden complex recovered from mountains near the town of Pella, South Africa (a full description of rock hyrax middens can be found in Chase et al., 2012). Through this analysis we seek to investigate: 1) the coherence between marine and terrestrial pollen records, 2) the extent that the former may be used as reliable indicators of changes in terrestrial ecosystems, and 3) the hypothesis that mediterranean Fynbos Biome expanded far to the north during the last glacial period as a result of an equatorward shift of the westerly storm track (e.g. Chase and Meadows, 2007; Shi et al., 2000; Shi et al., 2001).

\section{STUDY REGION AND SITE DESCRIPTION}

The Pella midden site $\left(29^{\circ} 00^{\prime} 04^{\prime \prime} \mathrm{S}, 19^{\circ} 08^{\prime} 06^{\prime} \mathrm{E}, 490 \mathrm{~m}\right.$ amsl.) is located $3 \mathrm{~km} \mathrm{NNW}$ of the town of Pella, on the South African southern flank of the Orange River valley, $4 \mathrm{~km}$ from the

river (Figure 1). Lower than the surrounding plains, which receive c. $200 \mathrm{~mm} \mathrm{yr}^{-1}$ of rainfall, the climate of the Orange River valley is arid to hyperarid, with the midden site receiving 
only c. $70 \mathrm{~mm} \mathrm{yr}^{-1}$ of rainfall (Hijmans et al., 2005). Most (66\%) of what little rainfall the region receives falls during the late summer, placing the site on the border of the western margin of southern Africa's summer rainfall zone (SRZ; sensu Chase and Meadows, 2007). Compounding the effects of low rainfall and strong seasonality, inter-annual variability of precipitation is high, and the region may go for several years with no rainfall.

The vegetation at Pella (Figure 1) is classified as Eastern Gariep Rocky Desert, with the plains immediately to the south hosting Eastern Gariep Plains Desert vegetation (Mucina and Rutherford, 2006a), representing an extension of the hyperarid - arid extension of the Namib Desert across the more humid Succulent Karoo and Nama-Karoo biomes (Figure 1). Indeed, vegetation on the rocky slopes around the site is extremely sparse. As the site is found in a structure created by a drainage line (Figure 2d), some larger shrubs (e.g. Searsia (a.k.a. Rhus) sp. (Anacardiacae)) are found in close proximity (Figure 3). While no Aloe were observed at the site, they are an important tree/shrub element of the ecoregion, as are species of Acacia, Boscia, Euclea, Maerua and Pappea. Smaller shrubs include Commiphora sp, Ruschia, Mesembryanthenum, Tylecodon, Zygophyllum, Diospyros, Eriocephalus, Hermannia, Justicia, Monechma and Petalidium, and Tribulus is one of the primary perennial herbs. The surrounding plains host somewhat denser vegetation (Figure 2c; Figure 3), dominated by species of Stipagrostis grass and Euphorbia and Zygophyllum shrubs as well as localised stands of Aloe dichotoma (Mucina and Rutherford, 2006a). In this and drier regions of the Desert Biome (e.g. Figure 2a), grasses are best adapted and most prevalent as they can withstand extended drought periods and respond quickly when rain does fall. Woody shrubs may be found along drainage lines or other locations that store groundwater (Figure 2d; Figure 3), but these situations become increasingly rare in drier environments.

Approximately $20-30 \mathrm{~km}$ to the south of the site, increased rainfall supports Bushmanland Arid Grassland vegetation of the Nama-Karoo Biome (Mucina and Rutherford, 2006a) (Figure 2b). As a whole, the Nama-Karoo is distinguished from the adjacent 
Succulent Karoo Biome to the west by seasonality of rainfall (summer as opposed to winter rainfall dominance), and its relatively low plant diversity, with Asteraceae and Poaceae being the dominant families (Mucina and Rutherford, 2006a). A significant gradient in rainfall amount exists across the Nama-Karoo from east (c. $500 \mathrm{~mm} \mathrm{yr}^{-1}$ ) to west (c. $70 \mathrm{~mm} \mathrm{yr}^{-1}$ ). In the west, nearer to Pella, succulents of Aizoaceae, Crassulaceae and Euphorbiaceae become more common, reflecting the drier climate and the transition with the Succulent Karoo and Desert biomes. The Bushmanland Arid Grassland is similar in many respects to the Eastern Gariep Plains Desert described above, with a dominance of Stipagrostis grasses. Species of Aristida and Eragrostis grass also occur, and the tree species Acacia mellifera and Boscia foetida are found along drainage lines. Shrubs such as Lycium, Pentzia, Barleria, Berkhya, Blepharis, Eriocephalus, Hirpicium, Aizoon, Monechma, Solanum and Zygophyllum are most common, and Tribulus is again a common herb (Mucina and Rutherford, 2006a). Generally, grass dominates in the Nama-Karoo under two opposing climate regimes: 1) along its most arid margins, where there are insufficient groundwater resources to support perennial shrubs, and 2) with increasing rainfall, which becomes more regular/abundant to the east, where the Nama-Karoo grades into the Grassland Biome.

\section{MATERIAL AND METHODS}

\subsection{The Pella rock hyrax middens}

Rock hyrax middens are stratified accumulations of urine and/or faecal pellets that are deposited as successive layers, often over thousands of years (see Chase et al., 2012). The midden at Pella formed in several distinct lobes (Figure 3c). For this study, sections of two of the lobes of the midden complex were sampled for pollen analysis: PEL-1-1 (22 cm thick) and PEL-1-4a $(13.5 \mathrm{~cm})$. The samples from each (PEL-1-1 $\mathrm{n}=38$; PEL-1-4a $\mathrm{n}=21)$ midden are contiguous, with each consisting of a block of material 2-5 $\mathrm{mm}$ thick and weighing 
between $\sim 0.3 \mathrm{~g}$ and $1.0 \mathrm{~g}$. For a full description of hyrax middens, their development and the sampling and analytical methodologies for the proxies they contain, see Chase et al. (2012).

Radiocarbon analysis was performed on 16 samples from the midden section (PEL1-1, $\mathrm{n}=10$; PEL-1-4a, $\mathrm{n}=6$ ). The samples were pretreated with $2 \% \mathrm{HCl}$ for one hour at room temperature to remove carbonates and dried at $60^{\circ} \mathrm{C}$. They were then weighed into quartz tubes with an excess of $\mathrm{CuO}$, sealed under vacuum and combusted to $\mathrm{CO}_{2}$. The $\mathrm{CO}_{2}$ was converted to graphite on an iron catalyst using the zinc reduction method (Slota et al., 1987). The ${ }^{14} \mathrm{C} /{ }^{12} \mathrm{C}$ ratio and ${ }^{13} \mathrm{C} /{ }^{12} \mathrm{C}$ were measured by accelerator mass spectrometry (AMS) at the ${ }^{14}$ CHRONO Centre, Queen's University Belfast.

All the radiocarbon ages were calibrated (Table 1) with the Southern Hemisphere calibration data (SHCal13, Hogg et al., 2013; Reimer et al., 2013) and chronologies were estimated with the Bacon v2.2 model (Blaauw and Christen, 2011). Bacon produces robust estimations of the probability density function $(p d f)$ of the uncertainties associated with our pollen samples. That information, referred to as $p d f_{\text {age, }}$ was extracted and integrated in a framework to derive robust quantitative climate reconstructions (more details below and in Chevalier and Chase, 2015).

\subsection{Pollen and microcharcoal analysis}

Pollen samples were prepared with standard physical (600 $\mu \mathrm{m}$ sieving and decanting) and chemical (HCl, KOH, HF and acetolysis) methods (Moore et al., 1991). Lycopodium tablets were added to the weighed sample to estimate pollen concentrations (Stockmarr, 1971). A minimum pollen sum of 400 grains was counted at a magnification of $\times 400$ under a light microscope, and identified with the help of the literature (Scott, 1982a; van Zinderen Bakker, 1953, 1956; van Zinderen Bakker and Coetzee, 1959), and photographic and slides reference collections at the University of the Free State, University of Cape Town, and University of Montpellier. Microcharcoal particles were identified as black, completely opaque, angular 
fragments that occurred in the pollen slides (Clark, 1988). Only charcoal particles $>75 \mu \mathrm{m}^{2}$ (or longer than $10 \mu \mathrm{m}$ ) were counted under a light microscope at $\times 400$ magnification (Mooney and Tinner, 2011; Patterson et al., 1987). A minimum count of 200 items (given by the sum of charcoal particles and exotic marker grains) was used. Charcoal particles which exceed the mesh-width size of $600 \mu \mathrm{m}$ are missing from the microscopic charcoal record and particles of ca. $<10 \mu \mathrm{m}$ were not counted in order to ensure correct identification (Mooney and Tinner, 2011). Therefore, our charcoal signal is related primarily to the regional fire signal, with specifically local fires (large particles) and remote, extra-regional fires $(<10 \mu \mathrm{m}$ particles) being excluded.

The TILIA program was used to construct the pollen diagrams, and pollen zones are determined by the CONISS method (Grimm, 2011).

\subsection{Climate reconstruction from fossil pollen}

To derive more specific palaeoclimatic information, we used the CREST software package (Climate REconstruction SofTware; Chevalier et al., 2014) to analyse the fossil pollen data from Pella. In this paper, we focus on the reconstruction of an aridity index (AI) and mean annual temperature (MAT).

The method is based on the use of $p d f$ s. Modern plant distributions, obtained from the South African National Botanical Institute (Rutherford et al., 2012; Rutherford et al., 2003; SANBI, 2003), are correlated with AI (Trabucco and Zomer, 2009) and MAT (Hijmans et al., 2005) data to define climatic envelopes for plant species and fit species $p d f \mathrm{~s}\left(p d f_{\mathrm{sp}}\right)$. These $p d f_{\mathrm{sp}}$ are then combined according to the individual species that comprise each fossil pollen type identified in the sequence to create a pollen $p d f\left(p d f_{\text {pol }}\right)$. Finally, the $p d f_{\text {pol }}$ for each sample are weighted and multiplied to produce a curve that represents the likelihood of AI/MAT based on the coexistence of the different taxa $\left(p d f_{\mathrm{AI}} / p d f_{\mathrm{MAT} .}\right)$. 
The CREST method has been shown to be sensitive to the number of taxa used (Chevalier et al., 2014). Juggins et al. (2015) and Chevalier and Chase (2015) have also shown - for different reconstruction methods - that selecting a subset of sensitive taxa was preferable to ensure robust quantifications from pollen data. Using the CREST software package and its diagnostics tools (based on assessments of the shape of the pollen $p d f$ s $(e . g$. number of modes, kurtosis) and the modern correlation between plant distributions and climate gradients, we selected a subset of sensitive taxa for: 1) AI (Aizoaceae, Aizoon type, Amaryllidaceae, Anacardiaceae, Apiaceae, Caryophyllaceae, Celastraceae, Crassula, Forsskaolea, Menispermaceae, Montinia, Pappea, Pentzia-type, Petalidium, Stoebe-type, Tribulus, Rhamnaceae and Zygophyllum) and 2) MAT (Amaryllidaceae, Apiaceae, Berkheya, Capparaceae, Caryophyllaceae, Crassula, Ericaceae, Forsskaolea, Hermannia, Justicia, Montinia, Moraceae and Stoebe-type). Species-rich taxa such as Asteraceae, Poaceae and Scrophulariaceae cannot be used due to the saturation effect of the CREST method (further details available in Chevalier et al., 2014).

To enhance the signal over noise ratio of our reconstructions, we used the two-step Monte-Carlo framework presented in (Chevalier and Chase, 2015). Each sample is associated with quantified uncertainties from: 1) the CREST reconstruction $\left(p d f_{\mathrm{AI}} / p d f_{\mathrm{MAT}}\right)$, and 2) the $p d f$ of the age uncertainties derived from the age-depth model ( $\left.p d f_{\text {age }}\right)$. To interpolate the reconstructions and integrate these two sources of uncertainty, different scenarios are built by sampling $p d f_{\mathrm{AI}} / p d f_{\mathrm{MAT}}$ and $p d f_{\text {age }}$ for each sample. The accumulation and combination of 100,000 of those scenarios produces a robust interpolated curve that integrates uncertainties from the age-depth model and the reconstruction process. The interpolated curves are then stacked together (centred using their overlapping sections between 100 and 1300 cal BP (calibrated radiocarbon years before $\mathrm{AD}$ 1950)) with a second round of Monte-Carlo sampling to produce a single reconstruction. This process generates high-frequency, low- 
amplitude white noise that has no climate or environmental significance, and which is filtered out with a 1000-yr moving average.

\section{$4 \quad$ RESULTS}

\subsection{Age-depth models and midden accumulation rates}

The radiocarbon analyses of the Pella middens PEL-1-4a and PEL-1-1 indicates that each lobe accumulated continuously, although with significant changes in accumulation rate (Figure 4). An exception may be at $\sim 15.75 \mathrm{~cm}$ in PEL-1-1 where a sharp decrease or cessation of accumulation may have occurred. Accumulation rates range from extremes of $4.9 \mathrm{yr} / \mathrm{mm}$ in PEL-1-4a to $780 \mathrm{yr} / \mathrm{mm}$ in PEL-1-1, with average accumulation rates of 230 $\mathrm{yr} / \mathrm{mm}$ (PEL-1-1) and $9 \mathrm{yr} / \mathrm{mm}$ (PEL-1-4a). This identifies minimum and maximum resolutions of 10 and 2358 cal year per sample, and average resolutions of $950 \pm 515$ (PEL-11) and $40 \pm 10$ (PEL-1-4a) cal year per sample.

\subsection{Vegetation dynamics inferred from pollen record}

The Pella middens (PEL-1-1 and PEL-1-4a) are integrated into a single record (one sample from PEL-1-1 at $\sim 630$ cal BP with PEL-1-4a), with a total of fifty-one identified taxa being divided, and samples being clustered into seven statistically significant pollen zones spanning the last 50,000 years (Figure 5). Poaceae and Asteraceae are the most common and persistent pollen types occurring, with Asteraceae being most prevalent during periods of the late Pleistocene (particularly from 50 - 39 cal kBP and 32 - 15 cal kBP (thousand calibrated radiocarbon years before AD 1950)) and grasses - along with certain succulents and woody elements - becoming more dominant during the Holocene. 


\subsubsection{Pleistocene vegetation composition and dynamics}

The lowermost pollen zone (PEL-I; $\sim 50-\sim 39$ cal kBP) is characterised by early peaks in Menispermaceae, Olea, Anacardiaceae (incl. Searsia/Rhus-type) and Cyperaceae pollen, followed by a general dominance of Asteraceae until 42 cal kBP, when it is replaced by consecutive peaks of Zygophyllum, Anacardiaceae and Cyperaceae pollen (Figure 5). Trilete psilate spores are also consistently present, and even abundant during PEL-I. Pollen zone PEL-II $(\sim 39-\sim 32$ cal kBP) is defined by relatively low percentages of Asteraceae pollen, and significant increases in Anacardiaceae, Dicliptera-type and Scrophulariaceae pollen. Subsequently, zone PEL-III ( 32 - 27 cal kBP), is characterised by the disappearance of Anacardiacae and Dicliptera-type pollen, the appearance of Pappea and spikes in Zygophyllum pollen (comprising as much as $91 \%$ of the pollen assemblage). PEL-IV ( $27-$ $\sim 17$ cal $\mathrm{kBP})$ is dominated by Asteraceae pollen types. This increase in Asteraceae in PEL-III and PEL-IV is accompanied by the more regular abundance of succulents such as Aizoaceae, Aizoon-type and Euphorbia. In PEL-IV, Poaceae pollen becomes notably less abundant. Menispermaceae pollen declines and disappears across this period, and more generally, arboreal pollen is largely absent, particularly between $\sim 24-17$ cal kBP.

\subsubsection{Deglacial and Holocene vegetation composition and dynamics}

Pollen zone PEL-V, from $\sim 17-6.5 \mathrm{cal} \mathrm{kBP}$, spans the last glacial-interglacial transition (LGIT) and the early Holocene. Beginning at $\sim 14$ cal kBP, marked increases in arboreal pollen (particularly Pappea and Anacardiaceae, but also Celastraceae in lower percentages) are apparent, as is a sharp decline in Asteraceae pollen types (Figure 5). Poaceae pollen percentages also increase across this zone, reaching a maximum between $\sim 9.6-6.5$ cal $\mathrm{kBP}$. This increase in Poaceae is paralleled by a decline in the aforementioned arboreal taxa, with Anacardiacae being reduced to trace levels after $\sim 7$ cal kBP. Pollen zones PEL-VI and PELVII ( $~ 6.5-1.7$ cal kBP and $\sim 1.7$ cal kBP to present, respectively) are most clearly defined by 
significant increases in Heliophila and Forsskaolea pollen. Pappea pollen percentages increase for a short time in early PEL-VI (peaking at $~ 5.1 \mathrm{cal} \mathrm{kBP}$ ), but declines again after $\sim 4.5$ cal kBP. Poaceae pollen percentages remain high from $~ 9.6$ cal kBP throughout PEL-VI and PEL-VII. PEL-VII is similar to PEL-VI, although of significantly higher resolution (a result of the higher accumulation rates of the PEL-1-4a midden). Notable are increases in Forsskaolea pollen between $\sim 1.5-0.8 \mathrm{cal} \mathrm{kBP}$, followed by its decline, and increases in Zygophyllum pollen after $\sim 0.8 \mathrm{cal} \mathrm{kBP}$ and an increase in Scrophulariaceae pollen from $\sim 0.5$ cal kBP until the end of the sequence.

\subsection{Pollen-based climate reconstructions}

Reconstructions of temperature from the Pella pollen data indicate a predictable pattern of cooler glacial and warmer interglacial conditions (Figure 8a). The absolute quantitative accuracy of the pollen-based reconstruction is limited by the number of true temperature dependent taxa (relying heavily on Stoebe-type and Forsskaolea pollen percentages), which is reflected in the low amplitude of variability. Taking the reconstructed values as relative index, however, it is apparent that the transition from cool glacial-age conditions to nearmodern temperatures in the Holocene began at $\sim 19$ cal kBP and continued until $\sim 9$ cal kBP.

The AI reconstruction (Figure $8 \mathrm{~b}$ ) highlights the major trends inferred from the pollen record, with each of the seven pollen zones generally being associated with specific climate states and/or variability. During the 50,000 years covered by the Pella record, the AI reconstruction presents three different modes. In the oldest section (PEL-I to PEL-IV), the climate is relatively humid but highly variable, with alternating wet $(\sim 50,44,34,29$ and 24 cal kBP) and dry ( 47, 38, 32, 26 and 20 cal kBP) phases. Conditions during the LGM 2418 cal kBP appear to be more stable, and relatively dry in comparison with the rest of the glacial period, but reconstructions around the LGM should be treated with some caution as during this period midden accumulation rates were low (with high temporal uncertainties), 
and the vegetation was dominated by Asteraceae, with a limited number of taxa available for the reconstruction (Figures 5 and 7). PEL-V spans the LGIT and is marked by a broad phase of increased humidity from $\sim 16-10$ cal kBP followed by a sharp aridification that - with the exception of a relatively wet event around 6 cal kBP - continues across PEL-VI. Conditions were most arid at the end of PEL-VI ( 2.5 cal kBP), while the last two millennia (PEL-VII) are associated with increased humidity in the region.

The influence of each pollen type on the MAT and AI reconstructions is measured by a Leave-One-Out (LOO) approach, which consists of performing reconstructions without the given taxon. The difference between the reconstructions with and without the taxon provides insight into its climatic significance, both in term of sign and amplitude (Fig. 6 and 7). It should be noted that the sign of the signal - whether it is negative or positive - is relative, depending on the other taxa observed in the assemblage, and the reconstructed climatic context (e.g. Pentzia-type is a wet indicator during the Holocene and a dry indicator during the last glacial period, Fig. 7).

\section{DISCUSSION}

\subsection{Climate and vegetation at Pella}

The pollen records from the Pella rock hyrax middens show marked changes in the vegetation at the site, indicating substantial variability in moisture availability and temperature. Using the CREST method (Chevalier et al., 2014) described above, we have quantified these changes by reconstructing AI and MAT, creating records of climate change spanning the last 50 cal kBP.

\subsubsection{The last glacial period $(\sim 50-12$ cal $\mathrm{kBP})$}

Considered as a whole, the last glacial period at Pella was characterised by cool climates and generally significantly greater moisture availability (Figures 8 and 9). The temperature index 
reconstructed here shows marked similarities with the palaeotemperature record obtained from the Stampriet Aquifer (Stute and Talma, 1998), with both indicating that deglacial warming began immediately after the LGM, at $\sim 19$ cal kBP (Figure 9). It is likely that changes in temperature had an influence on moisture availability (Chevalier and Chase, in press), at least at the scale of glacial-interglacial variability, but differences between the two reconstructions suggest that changes in rainfall amount may have also played a significant role over shorter timescales (Figure 9).

The pollen data and AI reconstruction indicate relatively high amplitude fluctuations in moisture availability during marine isotope stage (MIS) 3 (24 - 59 ka). This is reflected in increased percentages of Pappea, Celastraceae and Anacardiaceae pollen during wetter phases, and more abundant succulents such as Aizoaceae and Aizoon-type pollen during relatively drier phases. It cannot be clearly differentiated from the pollen data whether the dominant vegetation at the site during this period was Nama-Karoo or Desert, but 1) its position on the modern ecotone, 2) the indications for increased humidity and 3) the abundance of Asteraceae pollen would suggest an expansion of the Nama-Karoo during this time. While Asteraceae and Poaceae are too widespread to be used for the reconstruction of specific palaeoclimatic variables, they are the dominant elements of the Nama-Karoo vegetation, and their relative abundance may - in a broad sense, within this biome - be considered as proxy for general aridity. Across the Nama-Karoo, Poaceae (Asteraceae) becomes more dominant with increasing humidity (aridity), with the Nama-Karoo grading into the Grassland Biome as rainfall increases to the east in South Africa. During the last glacial period, the humid conditions before $\sim 27 \mathrm{cal} \mathrm{kBP}$ promoted the general development of grasses, and a relatively mesic Nama-Karoo vegetation. This is likely the result of more/more regular rain or a reduction in potential evapotranspiration, which resulted in increased water-availability for shallow rooting grasses. The increased aridity during the LGM sees a significant decline in grasses, along with most arboreal taxa, leaving a 
predominantly asteraceous vegetation, similar to drier regions of the Nama-Karoo. The humid period following the LGM is marked by the recurrence of arboreal taxa such as Anacardiaceae, Celastraceae, Capparaceae and Pappea, and a clear increase in grasses as Asteraceae pollen percentages decline sharply.

It is interesting to note that this phase of increased humidity correlates with a major period of dune activity in the adjacent southwestern Kalahari, which has been identified as occurring between 15 - $9 \mathrm{ka}$ (Telfer and Thomas, 2007). These dune data, and inferences based on marine pollen records (Shi et al., 2000), had been thought to indicate drier conditions during this period, but these conclusions are inconsistent with the findings in this paper, and those from other terrestrial sites along the southwest African margin (Chase et al., 2015; Chase et al., 2010; Chase et al., 2009), and other marine records that indicate reduced wind strength/upwelling at this time (Farmer et al., 2005; Kim et al., 2003; Pichevin et al., 2005; Stuut et al., 2002). This apparent contradiction has been highlighted by Chase et al. (2010), who have suggested that the "aridification" (Shi et al., 2000) observed in the marine records may be dominated by a reduction in pollen source area as a function of reduced wind strength (resulting in a preponderance of arid Namib Desert pollen), and that the elevated number of dune ages from this period in fact reflects a cessation of dune activity - similarly related to reduced wind strength - and the subsequent preservation of these sediments in the more stable Holocene landscape (Chase and Thomas, 2006).

Comparing mean climate states for the glacial and interglacial periods, glacial AI values are substantially higher $(0.28$ for the period from $10-50$ cal $\mathrm{kBP}$, and 0.18 for the Holocene). While the reconstructed AI value for the Pella site is $\sim 0.1$ higher than the values derived from the data of Trabucco and Zomer (2009), this may be explained by either microclimatic/hydrologic factors related to the east-facing aspect of the site, its architecture and position in a shallow drainage feature (Figure 3 and $2 \mathrm{~d}$ ), or reflect complications in the reconstructions as the log-normal $p d f_{\text {sp }}$ reach 0 . Correcting for this, moisture availability in 
the Pella region during the last glacial period was apparently more akin to the relatively humid eastern Nama-Karoo, with phases of peak humidity (AI values of $~ 0.35$ ) perhaps even approaching the transition to the Grassland Biome.

One aspect of glacial vegetation dynamics in this region has been the question of whether the mediterranean Fynbos Biome expanded into the region as a result of an equatorward shift of the westerly storm track and regional 'winter-rainfall zone' driven by an expanded circumpolar vortex (Chase and Meadows, 2007; Cockcroft et al., 1987; van Zinderen Bakker, 1976). In the absence of long, continuous terrestrial sequences, fossil pollen recovered from marine cores (Shi et al., 2000; Shi et al., 2001; Urrego et al., 2015) has been used to infer vegetation change in southwestern Africa across the last glacial-interglacial cycle, with conclusions generally supporting the early conceptual models (e.g. van Zinderen Bakker, 1976). The significance of these data, however, remains a subject of debate, with points of contention relating to: 1) the choice of taxa that are considered as fynbos indicators, and 2) the taphonomy of the pollen sequences.

The Fynbos Biome experiences a predominantly winter rainfall regime and a cool growing season. As such, it is characterised by taxa with affinities for lower temperatures such as Ericaceae, Restionaceae, Proteaceae, Artemisia, Stoebe-type and Passerina. This has led some researchers to consider elevated percentages of these taxa in glacial-age sediments from Namibian marine cores as evidence for expansions of the Fynbos Biome (Shi et al., 2000; Shi et al., 2001; Urrego et al., 2015). It must be kept in mind, however, that these taxa are not restricted to the Fynbos Biome. Rather, particularly in the case of Artemisia and Stoebe-type (Stoebe and Elytropappus rhinocerotis) (Urrego et al., 2015), these plants occur across southern Africa where there is enough moisture to meet their requirements, and temperatures during the wet season are below $21^{\circ} \mathrm{C}$ (Rutherford et al., 2012; Rutherford et al., 2003; SANBI, 2003; Urrego et al., 2015). A temperature depression of $4-6^{\circ} \mathrm{C}$ during the last glacial period, as estimated from regional palaeotemperature records (Chevalier and 
Chase, 2015; Kulongoski and Hilton, 2004; Stute and Talma, 1998; Talma and Vogel, 1992;

Truc et al., 2013), would have led to a significant increase in the prominence and spatial distribution of these taxa, as is indicated in pollen records from across the subcontinent (Coetzee, 1967; Scott, 1982b, 1989, 1999; Scott et al., 2004; Scott et al., 2012).

Of the taxa that are considered to be fynbos indicators, Restionaceae is the closest to being exclusive to the biome. As such, it has been considered to be a key element in determining possible palaeo-expansions of the Fynbos Biome by Shi et al. $(2000 ; 2001)$ However, Restionaceae are wind pollinated, and data from surface samples indicate that it can represent a significant percentage of the total pollen rain far downwind of the plant's distribution (Rutherford et al., 2012; Rutherford et al., 2003; SANBI, 2003). Unlike the pollen assemblages from the marine sequences, wherein Restionaceae pollen is abundant, Scott et al. (2004) found no pollen of these taxa in similar age hyrax middens from the Brandberg of central Namibia. This discrepancy between terrestrial and marine records led Scott et al. to suggest that the intensification of the atmospheric and oceanic circulation systems associated with the Benguela Upwelling System during the last glacial period (cf. Farmer et al., 2005; Little et al., 1997; Pichevin et al., 2005; Stuut et al., 2002) would have increased the long-distant transport of pollen from the Fynbos Biome, and that the biome itself did not expand significantly. While it could be argued that as the Brandberg is $~ 1000$ $\mathrm{km}$ north of the present limits of the Fynbos Biome, and a significant expansion of the biome may still have occurred, the data from the Pella middens, as well as that from the Richtersveld mountains to the west (Scott et al., 1995), suggests that this was not the case. Only $\sim 150 \mathrm{~km}$ northeast of the northern fynbos remnants in the Kammiesberg mountains, Restionaceae pollen at Pella never exceeds $1 \%$ of the pollen assemblage (Figure 5). This indicates that any expansion of the Fynbos Biome must have been very restricted, and that the elevated percentages of 'fynbos' pollen observed in marine cores more likely reflects: 1) generally cooler continental conditions, and 2) an increase in the long-distance transport of 
pollen with increased atmospheric and oceanic circulation intensity during the last glacial period.

\subsubsection{The Holocene (12 cal kBP to present)}

Interestingly, while the vegetation of the last glacial period seems to be broadly characterised by dynamics predicted for the Nama-Karoo Biome, the relationship between climate and key pollen types such as Asteraceae and Poaceae changes fundamentally during the Holocene. The increase in Poaceae pollen and decrease in Asteraceae pollen during the period of increased humidity following the LGM (from $\sim 16-10$ cal $\mathrm{kBP}$ ) may be interpreted as an increase in water-availability following the above-described model. However, despite the abrupt aridification after $10 \mathrm{cal} \mathrm{kBP}$, and the significantly drier conditions of the Holocene (observed also at Eksteenfontein in the nearby Richtersveld (Scott et al., 1995)), Poaceae pollen percentages remain at high level throughout the last 10,000 years. To explain this apparent inconsistency, the full environmental gradient across South Africa needs to be considered. As mentioned, with increased precipitation eastward in South Africa the NamaKaroo becomes increasingly grassy, eventually transitioning into the relatively humid Grassland Biome. To the northwest of the Pella site precipitation declines sharply, and there are insufficient groundwater resources to support the widespread development of shrubs such as the Asteraceae that define the arid eastern Nama-Karoo. As this component of the vegetation disappears, grasses once more become dominant in the Desert Biome (Figure 2a), exploiting the rare rains that do fall.

Considered from this perspective, it appears that the arid conditions that began at the beginning of the Holocene resulted in a shift in the Desert - Nama-Karoo ecotone, with the Desert Biome expanding along the Orange River Valley from its core along the coast. During this period, increases in Asteraceae pollen may indicate slightly more humid conditions, as indicated by the AI reconstructions, and at least minor expansions of the Nama-Karoo. 


\subsection{Palaeoenvironmental history of the southern Namib}

Considered in their regional context, results obtained from the Pella hyrax middens shed considerable light on the timing and mechanisms of climate change in the southern Namib Desert during the last 50,000 years. Despite the limited amplitude of the temperature reconstruction, as discussed above, the major temperature trends are consistent with the data from the nearby Stampriet Aquifer (Stute and Talma, 1998). Indications of increased humidity between $32-26$ cal kBP, $25-20$ cal kBP and $14-10$ cal kBP from fragmentary wetland and lacustrine sediments from further north and west in the Namib Desert and Richtersveld (Lancaster, 1984; Lancaster, 1986; Lancaster, 2002; Scott et al., 1995; Teller and Lancaster, 1985; Teller and Lancaster, 1986) are generally consistent with phases of increased humidity at Pella, with the caveat that such correlations remain duly speculative, in light of the nature of the records and the low resolution of the Pella record during the LGM. A key question regarding these findings is what drove this glacial-age increase in humidity. While such changes are often considered to be the result of increased rainfall amount, studies from eastern South Africa have shown that temperature may be at least as important as rainfall amount in regulating water availability (Chevalier and Chase, in press; Scott and Thackeray, 1987; Truc et al., 2013). First order changes across the last 50,000 years certainly appear to fit this model, with cool, humid conditions during the last glacial period, and warm, arid conditions during the Holocene.

Environmental variability in the broader region within the last glacial period has been attributed to direct insolation forcing following the precessional cycle. Originating in findings from the Tswaing Crater (Partridge et al., 1997), studies of pollen (Urrego et al., 2015), charcoal concentrations (Daniau et al., 2013) and leaf-wax $\delta \mathrm{D}$ and $\delta^{13} \mathrm{C}$ (Collins et al., 2014) from Namibian marine cores have also observed precessional cycles in their records, and inferred phases of increased humidity. In comparison, the data from Pella show no such 
correlation with the precessional cycle, with, if anything, a tendency for phases of increased humidity to occur during phases of reduced insolation (Figure 9). These findings challenge the assertion that the marine records reflect continental conditions and climate dynamics, indicating that they either reflect conditions in particular subregions, or that taphonomic rather than climatic controls are dominant determinants of the observed signals, as described above.

As direct insolation forcing does not adequately account for the significant AI variability observed at Pella during either the last glacial period or the Holocene, we compare our results with other indicators of changes in regional circulation systems. Of these, coastal upwelling, through the suppressed convection and the blocking of moisture-bearing systems from the east, has been shown to be an important factor in determining late Quaternary climate change in southwestern Africa (Chase et al., 2010; Chase et al., 2009). Comparing the Pella data with grain size analyses of Stuut et al. (2002) and the foraminifera data of Farmer et al. (2005), a complex, but coherent relationship can be observed. Throughout MIS 3 and the LGM (50 - 18 cal kBP), phases of increased humidity at Pella occur when atmospheric circulation intensity - and thus upwelling - increases (Figure 9). Of these episodes, those between $35-50$ cal kBP correlate strongly with temperature changes record in the Antarctic ice core from Dome C (Jouzel et al., 2007), with cooler periods being characterized by stronger winds (Farmer et al., 2005; Stuut et al., 2002). This relationship between cool conditions and increased upwelling continues until the beginning of the Holocene, although the link appears to be more generalized between $20-35 \mathrm{cal} \mathrm{kBP}$. As increased upwelling is expected to have an aridifying influence in southwestern Africa, we surmise that either its influence did not extend this far inland and/or the related changes in temperature reduced potential evapotranspiration during these periods, counteracting any reductions in precipitation. The period between $16-10 \mathrm{cal} \mathrm{kBP}$ deviates from the pattern of humid periods occurring under cooler conditions. After $17 \mathrm{ka}$, the warming recorded at Dome $\mathrm{C}$, the 
Stampriet Aquifer and Pella is paralleled by a sharp decrease in Benguela upwelling intensity (Figure 9). Pella experiences an increase in humidity during this transitional period between glacial and interglacial modes, likely as a result of dramatically reduced upwelling, allowing for increased local convection and the incursion of easterly air masses, while conditions were still relatively cool, limiting potential evapotranspiration. During the Holocene, high temperatures resulted in significantly more arid environments. Under these conditions, increases in upwelling strength are seen to intensify the arid conditions at Pella, with periods of enhanced upwelling and aridity occurring between $\sim 8-6$ cal $\mathrm{kBP}$ and $\sim 3.5-1.5$ cal $\mathrm{kBP}$ (Figure 9).

\section{CONCLUSIONS}

Analyses of fossil pollen data from subsections of a rock hyrax midden from Pella, South Africa provide a 50,000-year record of vegetation and climate change from the southern Namib Desert. Key findings include:

- The last glacial period was characterised by increased, but variable, water availability relative to Holocene, with changes in temperature and potential evapotranspiration playing a significant role in the hydrologic balance.

- During the last glacial period, the site was within the Nama-Karoo Biome, wherein increased aridity is reflected by an increase in Asteraceae pollen and a decrease in grasses.

- Episodes of increased humidity during the last glacial period occur during periods of increased upwelling. As increased upwelling has generally been found to increase aridity along the southwest African coast, concurrent declines in temperature and potential evaporation are implicated as significant drivers in these changes in the regional water balance. 
- Low Restionaceae pollen percentages $(\leq 1 \%)$ indicate no significant expansion of Fynbos Biome during the last 50,000 years.

- The last glacial-interglacial transition $(\sim 16-10$ cal $\mathrm{kBP})$ is characterised by increasing temperatures, markedly reduced upwelling, and increased water availability at Pella. While increasing temperatures would have resulted in increased drought stress, the influence of low upwelling intensity may have counteracted this by allowing for increased local convection and the incursion of moisture-bearing air masses.

- As temperatures reached Holocene maxima, conditions became significantly drier, and the Desert Biome expanded to encompass the Pella region.

- Under warm Holocene conditions, phases of increased aridity occur during periods of enhanced upwelling intensity.

\section{ACKNOWLEDGMENTS}

This work was funded by the European Research Council (ERC) under the European Union's Seventh Framework Programme (FP7/2007e2013)/ERC Starting Grant "HYRAX", grant agreement no. 258657. The authors also acknowledge the support of the South African National Botanical Institute (SANBI) in sharing their botanical data. This is an Institut des Sciences de l'Evolution - Montpellier, University Montpellier contribution, no. ISEM 2016$\operatorname{xxxx}$. 


\section{REFERENCES}

Global Ecoregions, in: Fund, T.W.W. (Ed.).

'ACACIA', S., 2002. Biomes in Namibia, Atlas of Namibia Project. Directorate of Environmental Affairs, Ministry of Environment and Tourism.

Bateman, M.D., Thomas, D.S.G., Singhvi, A.K., 2003. Extending the aridity record of the Southwest Kalahari: current problems and future perspectives. Quaternary International 111, 37-49.

Berger, A., Loutre, M.F., 1991. Insolation values for the climate of the last 10 million years. Quaternary Science Reviews 10, 297-317.

Blaauw, M., Christen, J.A., 2011. Flexible Paleoclimate Age-Depth Models Using an Autoregressive Gamma Process. Bayesian Analysis 6, 457-474.

Blümel, W.D., Eitel, B., Lang, A., 1998. Dunes in southeastern Namibia: evidence for Holocene environmental changes in the southwestern Kalahari based on thermoluminescence data. Palaeogeography, Palaeoclimatology, Palaeoecology 138, 139-149.

Blumel, W.D., Huser, K., Eitel, B., 2000. Climatic change and landscape development in the Namib Desert. Landschaftsveranderungen in der Namib

Geographische Rundschau 52, 17-23.

Bourke, M.C., Child, A., Stokes, S., 2003. Optical age estimates for hyper-arid fluvial deposits at Homeb, Namibia. Quaternary Science Reviews 22, 1099-1103.

Bristow, C.S., Duller, G.A.T., Lancaster, N., 2007. Age and dynamics of linear dunes in the Namib Desert. Geology 35, 555-558.

Butzer, K.W., 1984. Late Quaternary environments in South Africa, in: Vogel, J.C. (Ed.), Late Cainozoic palaeoclimates of the Southern Hemisphere. Proc. SASQUA symposium, Swaziland, 1983. Balkema, pp. 235-264.

Butzer, K.W., Stuckenrath, R., Bruzewicz, A.J., Helgren, D.M., 1978. Late Cenozoic paleoclimates of the Gaap Escarpment, Kalahari margin, South Africa. Quaternary Research 10, 310-339.

Chase, B., 2009. Evaluating the use of dune sediments as a proxy for palaeo-aridity: a southern African case study. Earth-Science Reviews 93, 31-45.

Chase, B.M., Boom, A., Carr, A.S., Carré, M., Chevalier, M., Meadows, M.E., Pedro, J.B., Stager, J.C., Reimer, P.J., 2015. Evolving southwest African response to abrupt deglacial North Atlantic climate change events. Quaternary Science Reviews 121, 132-136.

Chase, B.M., Brewer, S., 2009. Last Glacial Maximum dune activity in the Kalahari Desert of southern Africa: observations and simulations. Quaternary Science Reviews 28, 301-307.

Chase, B.M., Meadows, M.E., 2007. Late Quaternary dynamics of southern Africa's winter rainfall zone. Earth-Science Reviews 84, 103-138.

Chase, B.M., Meadows, M.E., Carr, A.S., Reimer, P.J., 2010. Evidence for progressive Holocene aridification in southern Africa recorded in Namibian hyrax middens: implications for African Monsoon dynamics and the "African Humid Period". Quaternary Research 74, 36-45. 
Chase, B.M., Meadows, M.E., Scott, L., Thomas, D.S.G., Marais, E., Sealy, J., Reimer, P.J., 2009. A record of rapid Holocene climate change preserved in hyrax middens from southwestern Africa. Geology 37, 703-706.

Chase, B.M., Scott, L., Meadows, M.E., Gil-Romera, G., Boom, A., Carr, A.S., Reimer, P.J., Truc, L., Valsecchi, V., Quick, L.J., 2012. Rock hyrax middens: a palaeoenvironmental archive for southern African drylands. Quaternary Science Reviews 56, 107-125.

Chase, B.M., Thomas, D.S.G., 2006. Late Quaternary dune accumulation along the western margin of South Africa: distinguishing forcing mechanisms through the analysis of migratory dune forms. Earth and Planetary Science Letters 251, 318-333.

Chase, B.M., Thomas, D.S.G., 2007. Multiphase late Quaternary aeolian sediment accumulation in western South Africa: timing and relationship to palaeoclimatic changes inferred from the marine record. Quaternary International 166, 29-41.

Chevalier, M., Chase, B.M., 2015. Southeast African records reveal a coherent shift from high- to low-latitude forcing mechanisms along the east African margin across last glacial-interglacial transition. Quaternary Science Reviews 125, 117-130.

Chevalier, M., Chase, B.M., in press. Determining the drivers of long-term aridity variability in southern Africa. Quaternary Science Reviews.

Chevalier, M., Cheddadi, R., Chase, B.M., 2014. CREST (Climate REconstruction SofTware): a probability density function $(p d f)$-based quantitative climate reconstruction method. Clim. Past 10 , 2081-2098.

Clark, J.S., 1988. Stratigraphic charcoal analysis on petrographic thin section: application to fire history in northwestern Minnesota. Quaternary Research 30, 81-91.

Cockcroft, M.J., Wilkinson, M.J., Tyson, P.D., 1987. The application of a present-day climatic model to the late Quaternary in southern Africa. Climatic Change 10, 161-181.

Coetzee, J.A., 1967. Pollen analytical studies in East and southern Africa. Palaeoecology of Africa 3, $1-146$.

Collins, J.A., Schefuß, E., Govin, A., Mulitza, S., Tiedemann, R., 2014. Insolation and glacialinterglacial control on southwestern African hydroclimate over the past 140000 years. Earth and Planetary Science Letters 398, 1-10.

Collins, J.A., Schefuß, E., Heslop, D., Mulitza, S., Prange, M., Zabel, M., Tjallingii, R., Dokken, T.M., Huang, E., Mackensen, A., Schulz, M., Tian, J., Zarriess, M., Wefer, G., 2011. Interhemispheric symmetry of the tropical African rainbelt over the past 23,000 years. Nature Geoscience 4, 42-45.

Cooke, H.J., Heine, K., 1979. Radiocarbon chronology of late Quaternary lakes in the Kalahari, southern Africa: a discussion. Catena 6, 107.

Daniau, A.-L., Sánchez Goñi, M.F., Martinez, P., Urrego, D.H., Bout-Roumazeilles, V., Desprat, S., Marlon, J.R., 2013. Orbital-scale climate forcing of grassland burning in southern Africa. Proceedings of the National Academy of Sciences 110, 5069-5073.

Deacon, J., Lancaster, N., 1988. Late Quaternary palaeoenvironments of southern Africa. Clarendon Press, Oxford. 
Eitel, B., Blümel, W.D., Hüser, K., 2002. Environmental transitions between $22 \mathrm{ka}$ and 8 ka in monsoonally influenced Namibia: a preliminary chronology. Zeitschrift fur Geomorphologie Suppl.Bd. 126, 31-57.

Eitel, B., Zöller, L., 1996. Soils and sediments in the basin of Dieprivier-Uitskot (Khorixas District, Namibia): age, geomorphic and sedimentological investigation, palaeoclimatic interpretation. Palaeoecology of Africa 24, 159-172.

Farmer, E.C., deMenocal, P.B., Marchitto, T.M., 2005. Holocene and deglacial ocean temperature variability in the Benguela upwelling region: implications for low-latitude atmospheric circulation. Paleoceanography 20, doi:10.1029/2004PA001049.

Gil-Romera, G., Scott, L., Marais, E., Brook, G.A., 2006. Middle- to late-Holocene moisture changes in the desert of northwest Namibia derived from fossil hyrax dung pollen. Holocene 16, 1073-1084.

Gil-Romera, G., Scott, L., Marais, E., Brook, G.A., 2007. Late Holocene environmental change in the northwestern Namib Desert margin: new fossil pollen evidence from hyrax middens. Palaeogeography, Palaeoclimatology, Palaeoecology 249, 1-17.

Gingele, F.X., 1996. Holocene climatic optimum in Southwest Africa: evidence from the marine clay mineral record. Palaeogeography, Palaeoclimatology, Palaeoecology 122, 77-87.

Grimm, E.C., 2011. Tilia version 1.7.16.

Heine, K., 1978. Radiocarbon chronology of the late Quaternary lakes in the Kalahari. Catena 5, 145149.

Heine, K., 1982. The main stages of the late Quaternary evolution of the Kalahari region, southern Africa. Palaeoecology of Africa 15, 53-76.

Heine, K., 2004. Little Ice Age climatic fluctuations in the Namib Desert, Namibia, and adjacent areas: evidence of exceptionally large floods from slack water deposits and desert soil sequences, Paleoecology of Quaternary Drylands, pp. 137-165.

Heine, K., Heine, J.T., 2002. A paleohydrologic reinterpretation of the Homeb Silts, Kuiseb River, central Namib Desert (Namibia) and paleoclimatic implications. Catena 48, 107-130.

Heine, K., Völkel, J., 2009. Desert flash flood series - Slackwater deposits and floodouts in Namibia: their significance for palaeoclimatic reconstructions. Zbl. Geol. Paläont. Teil I 2007, 287-308.

Hijmans, R., Cameron, S.E., Parra, J.L., Jones, P.G., Jarvis, A., 2005. Very high resolution interpolated climate surfaces for global land areas. International Journal of Climatology 25, 19651978.

Hogg, A.G., Hua, Q., Blackwell, P.G., Niu, M., Buck, C.E., Guilderson, T.P., Heaton, T.J., Palmer, J.G., Reimer, P.J., Reimer, R.W., Turney, C.S.M., Zimmerman, S.R.H., 2013. SHCal13 Southern Hemisphere Calibration, 0-50,000 Years cal BP.

Jouzel, J., Masson-Delmotte, V., Cattani, O., Dreyfus, G., Falourd, S., Hoffmann, G., Minster, B., Nouet, J., Barnola, J.M., Chappellaz, J., Fischer, H., Gallet, J.C., Johnsen, S., Leuenberger, M., Loulergue, L., Luethi, D., Oerter, H., Parrenin, F., Raisbeck, G., Raynaud, D., Schilt, A., Schwander, J., Selmo, E., Souchez, R., Spahni, R., Stauffer, B., Steffensen, J.P., Stenni, B., Stocker, T.F., Tison, J.L., Werner, M., Wolff, E.W., 2007. Orbital and millennial Antarctic climate variability over the past 800,000 years. Science 317, 793-797. 
Juggins, S., Simpson, G.L., Telford, R.J., 2015. Taxon selection using statistical learning techniques to improve transfer function prediction. The Holocene 25, 130-136.

Kim, J.-H., Schneider, R.R., Mulitza, S., Müller, P.J., 2003. Reconstruction of SE trade-wind intensity based on sea-surface temperature gradients in the Southeast Atlantic over the last 25 kyr. Geophysical Research Letters 30, 2144.

Kulongoski, J.T., Hilton, D.R., 2004. Climate variability in the Botswana Kalahari from the late Pleistocene to the present day. Geophysical Research Letters 31.

Lancaster, N., 1979. Evidence for a widespread Late Pleistocene humid period in the Kalahari. Nature 279, 145-146.

Lancaster, N., 1984. Paleoenvironments in the Tsondab Valley, central Namib Desert. Palaeoecology of Africa 16, 411-419.

Lancaster, N., 1986. Pans in the southwestern Kalahari: a preliminary report. Palaeoecology of Africa $17,59-67$.

Lancaster, N., 2002. How dry was dry?: Late Pleistocene palaeoclimates in the Namib Desert. Quaternary Science Reviews 21, 769-782.

Lancaster, N., Teller, J.T., 1988. Interdune deposits of the Namib Sand Sea. Sedimentary Geology 55, 91-107.

Lewis, S.C., LeGrande, A.N., Kelley, M., Schmidt, G.A., 2010. Water vapour source impacts on oxygen isotope variability in tropical precipitation during Heinrich events. Clim. Past 6, 325-343.

Little, M.G., Schneider, R.R., Kroon, D., Price, B., Bickert, T., Wefer, G., 1997. Rapid palaeoceanographic changes in the Benguela Upwelling System for the last 160,000 years as indicated by abundances of planktonic foraminifera. Palaeogeography, Palaeoclimatology, Palaeoecology 130, 135-161.

Mooney, S.D., Tinner, W., 2011. The analysis of charcoal in peat and organic sediments. Mires and Peat 7, 1-18.

Moore, P.D., Webb, J.A., Collinson, M.E., 1991. Pollen Analysis. Blackwell Scientific Publications, London.

Mucina, L., Rutherford, M.C., 2006a. The vegetation of South Africa, Lesotho and Swaziland. South African National Biodiversity Institute, Pretoria.

Mucina, L., Rutherford, M.C., 2006b. The vegetation of South Africa, Lesotho and Swaziland, Strelitzia. South African National Biodiversity Institute, Pretoria.

Partridge, T.C., deMenocal, P.B., Lorentz, S.A., Paiker, M.J., Vogel, J.C., 1997. Orbital forcing of climate over South Africa: a 200,000-year rainfall record from the Pretoria Saltpan. Quaternary Science Reviews 16, 1125-1133.

Patterson, W.A., Edwards, K.J., Maguire, D.J., 1987. Microscopic charcoal as a fossil indicator of fire. Quaternary Science Reviews 6, 3-23.

Pichevin, L., Cremer, M., Giraudeau, J., Bertrand, P., 2005. A 190 kyr record of lithogenic grain-size on the Namibian slope: forging a tight link between past wind-strength and coastal upwelling dynamics. Marine Geology 218, 81-96. 
Reimer, P.J., Bard, E., Bayliss, A., Beck, J.W., Blackwell, P.G., Bronk Ramsey, C., Grootes, P.M., Guilderson, T.P., Haflidason, H., Hajdas, I., Hatté, C., Heaton, T.J., Hoffmann, D.L., Hogg, A.G., Hughen, K.A., Kaiser, K.F., Kromer, B., Manning, S.W., Niu, M., Reimer, R.W., Richards, D.A., Scott, E.M., Southon, J.R., Staff, R.A., Turney, C.S.M., van der Plicht, J., 2013. IntCal13 and Marine13 Radiocarbon Age Calibration Curves 0-50,000 Years cal BP.

Rommerskirchen, F., Eglinton, G., Dupont, L., Güntner, U., Wenzel, C., Rullkötter, J., 2003. A north to south transect of Holocene southeast Atlantic continental margin sediments: Relationship between aerosol transport and compound-specific \&\#948;13C land plant biomarker and pollen records. Geochem. Geophys. Geosyst. 4, 1101.

Rutherford, M.C., Mucina, L., Powrie, L.W., 2012. The South African National Vegetation Database: History, development, applications, problems and future. South African Journal of Science 108.

Rutherford, M.C., Powrie, L.W., Midgley, G.F., 2003. ACKDAT: A digital spatial database of distributions of South African plant species and species assemblages. South African Journal of Botany 69, 99-104.

SANBI, 2003. PRECIS (National Herbarium Pretoria (PRE) Computerized Information System) database.

Schefuß, E., Kuhlmann, H., Mollenhauer, G., Prange, M., Patzold, J., 2011. Forcing of wet phases in southeast Africa over the past 17,000 years. Nature 480, 509-512.

Scott, L., 1982a. Late Quaternary fossil pollen grains from the Transvaal, South Africa. Review of Palaeobotany and Palynology 36, 241-278.

Scott, L., 1982b. Pollen analyses of late Cainozoic deposits in the Transvaal, South Africa, and their bearing on palaeoclimates (Sterkfontein). Palaeoecology of Africa 15, 101-107.

Scott, L., 1989. Climatic conditions in Southern Africa since the Last Glacial Maximum, inferred from pollen analysis. Palaeogeography, Palaeoclimatology, Palaeoecology 70, 345-353.

Scott, L., 1996. Palynology of hyrax middens: 2000 years of palaeoenvironmental history in Namibia. Quaternary International 33, 73-79.

Scott, L., 1999. Vegetation history and climate in the Savanna biome South Africa since 190,000 ka: a comparison of pollen data from the Tswaing Crater (the Pretoria Saltpan) and Wonderkrater. Quaternary International 57-8, 215-223.

Scott, L., Cooremans, B., de Wet, J.S., Vogel, J.C., 1991. Holocene environmental changes in Namibia inferred from pollen analysis of swamp and lake deposits. Holocene 1, 8-13.

Scott, L., Marais, E., Brook, G.A., 2004. Fossil hyrax dung and evidence of Late Pleistocene and Holocene vegetation types in the Namib Desert. Journal of Quaternary Science 19, 829-832.

Scott, L., Neumann, F.H., Brook, G.A., Bousman, C.B., Norström, E., Metwally, A.A., 2012. Terrestrial fossil-pollen evidence of climate change during the last 26 thousand years in southern Africa. Quaternary Science Reviews 32, 100-118.

Scott, L., Steenkamp, M., Beaumont, P.B., 1995. Palaeoenvironmental conditions in South Africa at the Pleistocene-Holocene transition. Quaternary Science Reviews 14, 937-947.

Scott, L., Thackeray, J.F., 1987. Mulivariate analysis of Late Pleistocene and Holocene pollen spectra from Wonderkrater, Transvaal, South Africa. South African Journal of Science 83, 93-98. 
Shi, N., Dupont, L.M., 1997. Vegetation and climatic history of southwest Africa: a marine palynological record of the last 300,000 years. Vegetation History and Archaeobotany 6, 117-131.

Shi, N., Dupont, L.M., Beug, H.-J., Schneider, R., 1998. Vegetation and climate changes during the last 21000 years in SW Africa based on a marine pollen record. Vegetation History and Archaeobotany 7, 127-140.

Shi, N., Dupont, L.M., Beug, H.-J., Schneider, R., 2000. Correlation between vegetation in southwestern Africa and oceanic upwelling in the past 21,000 years. Quaternary Research 54, 72-80.

Shi, N., Schneider, R., Beug, H.-J., Dupont, L.M., 2001. Southeast trade wind variations during the last 135 kyr: evidence from pollen spectra in eastern South Atlantic sediments. Earth and Planetary Science Letters 187, 311-321.

Slota, P.J., Jull, A.J.T., Linick, T.W., Toolin, L.J., 1987. Preparation of small samples for ${ }^{14} \mathrm{C}$ accelerator targets by catalytic reduction of CO. Radiocarbon 29, 303-306.

Srivastava, P., Brook, G.A., Marais, E., Morthekai, P., Singhvi, A.K., 2006. Depositional environment and OSL chronology of the Homeb silt deposits, Kuiseb River, Namibia. Quaternary Research 65, 478-491.

Stockmarr, J., 1971. Tablets with spores used in absolute pollen analysis. Pollen et Spores 13, 614621.

Stokes, S., Thomas, D.S.G., Shaw, P.A., 1997. New chronological evidence for the nature and timing of linear dune development in the southwest Kalahari Desert. Geomorphology 20, 81-93.

Stone, A.E.C., Thomas, D.S.G., 2008. Linear dune accumulation chronologies from the southwest Kalahari, Namibia: challenges of reconstructing late Quaternary palaeoenvironments from aeolian landforms. Quaternary Science Reviews 27, 1667-1681.

Stone, A.E.C., Thomas, D.S.G., Viles, H.A., 2010. Late Quaternary palaeohydrological changes in the northern Namib Sand Sea: New chronologies using OSL dating of interdigitated aeolian and waterlain interdune deposits. Palaeogeography, Palaeoclimatology, Palaeoecology 288, 35-53.

Stute, M., Talma, A.S., 1997. Isotope techniques in the study of past and current environmental changes in the hydrosphere and the atmosphere. IAEA Vienna Symposium 1997, Isotopic techniques in the study of environmental change. International Atomic Energy Agency, Vienna, pp. 307-318.

Stute, M., Talma, A.S., 1998. Glacial temperatures and moisture transport regimes reconstructed from noble gas and $\delta^{18} \mathrm{O}$, Stampriet aquifer, Namibia, Isotope Techniques in the Study of Past and Current Environmental Changes in the Hydrosphere and the Atmosphere. IAEA Vienna Symposium 1997, Vienna, pp. 307-328.

Stuut, J.-B.W., Prins, M.A., Schneider, R.R., Weltje, G.J., Jansen, J.H.F., Postma, G., 2002. A 300 kyr record of aridity and wind strength in southwestern Africa: inferences from grain-size distributions of sediments on Walvis Ridge, SE Atlantic. Marine Geology 180, 221-233.

Talma, A.S., Vogel, J.C., 1992. Late Quaternary paleotemperatures derived from a speleothem from Cango Caves, Cape Province, South Africa. Quaternary Research 37, 203-213.

Telfer, M., 2007. Late Quaternary aeolian activity and palaeoenvironments of the southwestern Kalahari: advances from an intensive chronometric investigation at Witpan, South Africa, School of Geography. University of Oxford, Oxford. 
Telfer, M.W., Thomas, D.S.G., 2007. Late Quaternary linear dune accumulation and chronostratigraphy of the southwestern Kalahari: implications for aeolian palaeoclimatic reconstructions and predictions of future dynamics. Quaternary Science Reviews 26, 2617-2630.

Teller, J.T., Lancaster, N., 1985. History of sediments at Khommabes, central Namib Desert. Madoqua 14, 267-278.

Teller, J.T., Lancaster, N., 1986. Lacustrine sediments at Narabeb in the central Namib Desert, Namibia. Palaeogeography, Palaeoclimatology, Palaeoecology 56, 177-195.

Teller, J.T., Rutter, N., Lancaster, N., 1990. Sedimentology and paleohydrology of late Quaternary lake deposits in the northern Namib Sand Sea, Namibia. Quaternary Science Reviews 9, 343-364.

Thomas, D.S.G., 2013. Reconstructing paleoenvironments and palaeoclimates in drylands: what can landform analysis contribute? Earth Surface Processes and Landforms 38, 3-16.

Thomas, D.S.G., Bailey, R., Shaw, P.A., Durcan, J.A., Singarayer, J.S., 2009. Late Quaternary highstands at Lake Chilwa, Malawi: frequency, timing and possible forcing mechanisms in the last 44 ka. Quaternary Science Reviews 28, 526-539.

Thomas, D.S.G., Burrough, S.L., 2012. Interpreting geoproxies of late Quaternary climate change in African drylands: implications for understanding environmental change and early human behaviour. Quaternary International 253, 5-17.

Thomas, D.S.G., Stokes, S., O'Connor, P.W., 1998. Late Quaternary aridity in the southwestern Kalahari Desert: new contributions from OSL dating of aeolian deposits, northern Cape Province, South Africa, in: Alsharhan, A.S., Glennie, K.W., Whittle, G.L., Kendall, C.G.S.C. (Eds.), Quaternary Deserts and Climatic Change. Balkema, Rotterdam.

Thomas, D.S.G., Stokes, S., Shaw, P.A., 1997. Holocene aeolian activity in the southwestern Kalahari Desert, southern Africa: significance and relationships to late-Pleistocene dune-building events. The Holocene 7, 273-281.

Trabucco, A., Zomer, R.J., 2009. Global Aridity Index (Global-Aridity) and Global Potential EvapoTranspiration (Global-PET) Geospatial Database. , in: Information, C.C.f.S. (Ed.). CGIAR-CSI GeoPortal, http://www.csi.cgiar.org.

Truc, L., Chevalier, M., Favier, C., Cheddadi, R., Meadows, M.E., Scott, L., Carr, A.S., Smith, G.F., Chase, B.M., 2013. Quantification of climate change for the last 20,000 years from Wonderkrater, South Africa: implications for the long-term dynamics of the Intertropical Convergence Zone. Palaeogeography, Palaeoclimatology, Palaeoecology 386, 575-587.

Urrego, D.H., Sánchez Goñi, M.F., Daniau, A.L., Lechevrel, S., Hanquiez, V., 2015. Increased aridity in southwestern Africa during the warmest periods of the last interglacial. Clim. Past 11, 1417-1431.

van Zinderen Bakker, E.M., 1953. South African pollen grains and spores. Part I. Balkema, Amsterdam/Cape Town.

van Zinderen Bakker, E.M., 1956. South African pollen grains and spores. Part II. Balkema, Amsterdam/Cape Town.

van Zinderen Bakker, E.M., 1976. The evolution of late Quaternary paleoclimates of Southern Africa. Palaeoecology of Africa 9, 160-202.

van Zinderen Bakker, E.M., Coetzee, J.A., 1959. South African pollen grains and spores. Part III. Balkema, Amsterdam/Cape Town. 
Vogel, J.C., 1982. The age of the Kuiseb river silt terrace at Homeb ( Namibia). Palaeoecology of Africa 15, 201-209.

Wang, Y.V., Larsen, T., Leduc, G., Andersen, N., Blanz, T., Schneider, R.R., 2013. What does leaf wax $\delta \mathrm{D}$ from a mixed $\mathrm{C} 3 / \mathrm{C} 4$ vegetation region tell us? Geochimica et Cosmochimica Acta 111, 128139.

Ward, J.D., 1984. A reappraisal of the Cenozoic stratigraphy in the kuiseb valley of the central Namib desert, in: Vogel, J.C. (Ed.), Late Cainozoic Palaeoclimates of the Southern Hemisphere. A.A. Balkema, Rotterdam, pp. 455-463.

Weldeab, S., Stuut, J.B.W., Schneider, R.R., Siebel, W., 2013. Holocene climate variability in the winter rainfall zone of South Africa. Clim. Past 9, 2347-2364. 


\section{Table captions}

Table 1: Radiocarbon ages and calibration information for the Pella-1-1 and Pella-1-4a hyrax middens.

Avg. depth ${ }^{14} \mathrm{C}$ age 1 sigmacalibration $95.4 \%(2 \sigma)$ cal relative area under Sample $(\mathrm{mm}) \quad$ yr BP error data age ranges distribution PEL-1-

1

UBA-

cal BP $1156-$

$22377 \quad 2.99$

$1302 \quad 26$

SHCal13

1270

0.752654

cal BP 1091 -

1153

0.247346

UBA-

cal BP 4235 -

$22378 \quad 28.38$

3950

29

SHCal13

4435

0.998603

cal BP $4194-$

4195

0.000652

cal BP 4185 -

4186

0.000745

UBA-

cal BP 6434 -

22379

$46.96 \quad 5767 \quad 33$

SHCal13

6635

0.978573

cal BP 6414 -

6426

0.021427

UBA-

cal BP 9538 -

$22380 \quad 57.89$

$8720 \quad 39$

SHCal13

9747

0.994191

$\begin{array}{llll}\text { cal } & \text { BP } & 9753 & -0.005809\end{array}$ 
9761

UBA-

cal BP 21942-

22381

89.75

$18408 \quad 94$

SHCal13

22446

cal BP 27501

UBA-

SHCal13 28086

$22382 \quad 121.76 \quad 23725 \quad 163$

cal BP 29409 -

UBA-

29409

$\begin{array}{lllllll}22383 & 132.6 & 25785 & 194 & \text { SHCal13 } & 30539 & 1\end{array}$

UBA-

cal BP 31062-

$\begin{array}{lllllll}22384 & 153.04 & 27717 & 239 & \text { SHCal13 } & 32043 & 1\end{array}$

UBA-

cal BP 37632-

$\begin{array}{lllllll}22385 & 162.75 & 34526 & 533 & \text { SHCal13 } & 40279 & 1\end{array}$

UBA-

cal BP 43380-

$\begin{array}{lllllll}22386 & 190.49 & 41451 & 785 & \text { SHCal13 } & 46159 & 1\end{array}$

PEL-1-

$4 a$

UBA-

SHCal13;

$21248 \quad 5.46$

$$
59
$$

27

SHZ1_2

*cal BP -6 - -5

0.151

*cal BP 31 - $56 \quad 0.554$

*cal BP 122 - 1320.295

UBA-

22397

$27.11 \quad 314 \quad 23$

SHCal13 cal BP 365- $443 \quad 0.527392$

cal BP 292- $331 \quad 0.472608$

UBA-

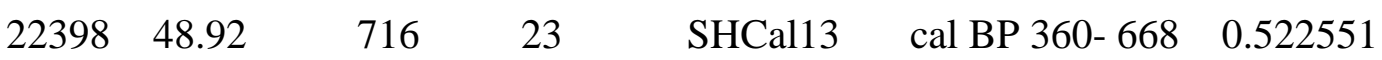


cal BP 564- $600 \quad 0.477449$

UBA-

$2239997.78 \quad 998 \quad 25 \quad$ SHCal13 cal BP 800-922 1

UBA-

$\begin{array}{lllllll}22400 & 110.67 & 1084 & 24 & \text { SHCal13 } & \text { cal BP 918-979 } & 0.998805\end{array}$

UBA-
cal BP 1039-
$1040 \quad 0.001195$
cal BP 1171-

$21249 \quad 133.51 \quad 1320 \quad 27$

SHCal13 $1278 \quad 0.906224$

cal BP 1095-

$1144 \quad 0.093776$

*Ages calibrated with Southern Hemisphere Zone 1 and 2 bomb curve extension; $1 \sigma$ ranges given 


\section{Figure captions}

Figure 1: Maps of aridity index (top) and the biomes of the southern Namib Desert region (bottom) with location of the Pella rock hyrax midden site. The data for vegetation type is derived from two separate sources for Namibia ('ACACIA', 2002) and South Africa (Mucina and Rutherford, 2006b). As the data differ in resolution and methodology, the desert region in Namibia was extended along the Orange River based on regional aridity index values $(<0.04)$ (Trabucco and Zomer, 2009) to be comparable with the South African data. The boundaries of the winter, year-round and summer rainfall zones (defined as $>66 \%, 66 \%-33 \%$ and $<33 \%$ winter Apr-Sept rainfall; (defined as $>66 \%, 66 \%-33 \%$ and <33\% winter Apr-Sept rainfall; sensu Chase and Meadows, 2007) are indicated by the grey NW-SE trending lines.

Figure 2: Images of the grassy plains of the Desert Biome (2a), the Bushmanland Arid Grassland vegetation of the Nama-Karoo Biome (2b), the Eastern Gariep Plains Desert (2c) and the Eastern Gariep Rocky Desert, with the Pella midden site indicated within the white circle (2d).

Figure 3: Images of the view from the Pella rock hyrax midden site, looking east (2a), the overhang sheltering the midden site (2b) and the Pella rock hyrax midden, with PEL-1-1 and PEL-1-4a lobes labelled (72 mm camera lens cover for scale) (2c).

Figure 4: Age models for the Pella rock hyrax middens PEL-1-1 and PEL-1-4a.

Figure 5: Diagram of pollen percentage and microcharcoal concentration data $(5 \mathrm{x}$ exaggeration) from the Pella rock hyrax middens PEL-1-1 and PEL-1-4a. Triangles blue represent ${ }^{14} \mathrm{C}$ dates (PEL-1-1 in blue, PEL-1-4a in orange).

Figure 6: Results of the leave-one-out cross-validation (LOOCV) analysis of the PEL-1-1 and PEL-1-4a pollen sequences for the temperature reconstructions. The importance of the pollen types for the reconstruction is indicated by the length of the bars, as is their influence in terms of reconstructing colder (blue bars) or warmer conditions (red bars) for a given sample. 
Figure 7: Results of the leave-one-out cross-validation (LOOCV) analysis of the PEL-1-1 and PEL-1-4a pollen sequences for the Aridity Index reconstructions. The importance of the pollen types for the reconstruction is indicated by the length of the bars, as is their influence in terms of reconstructing wetter (blue bars) or drier conditions (brown bars) for a given sample.

Figure 8: Reconstruction with $30 \%$ and $50 \%$ errors of mean annual temperature (TmeanAnn) (a) and aridity (AI) (b) at Pella derived from the PEL-1-1 and PEL-1-4a pollen data using the CREST software package (Chevalier et al., 2014). Black bars indicate the age range of each pollen sample analysed.

Figure 9: Comparison diagram of the Pella temperature index (a), the palaeotemperature record from the Stampriet Aquifer (b; Stute and Talma, 1998), the palaeotemperature record from the Dome C Antarctic ice core (c; Jouzel et al., 2007), marine records of wind strength in the Benguela Upwelling System derived from foraminifera (d; Farmer et al., 2005) and particle size data (e; Stuut et al., 2002), the $\delta$ D record from marine core MD08-3167 (f; Collins et al., 2014), the Pella Aridity Index record (g), and December insolation at $30^{\circ} \mathrm{S}$ (h; Berger and Loutre, 1991). 


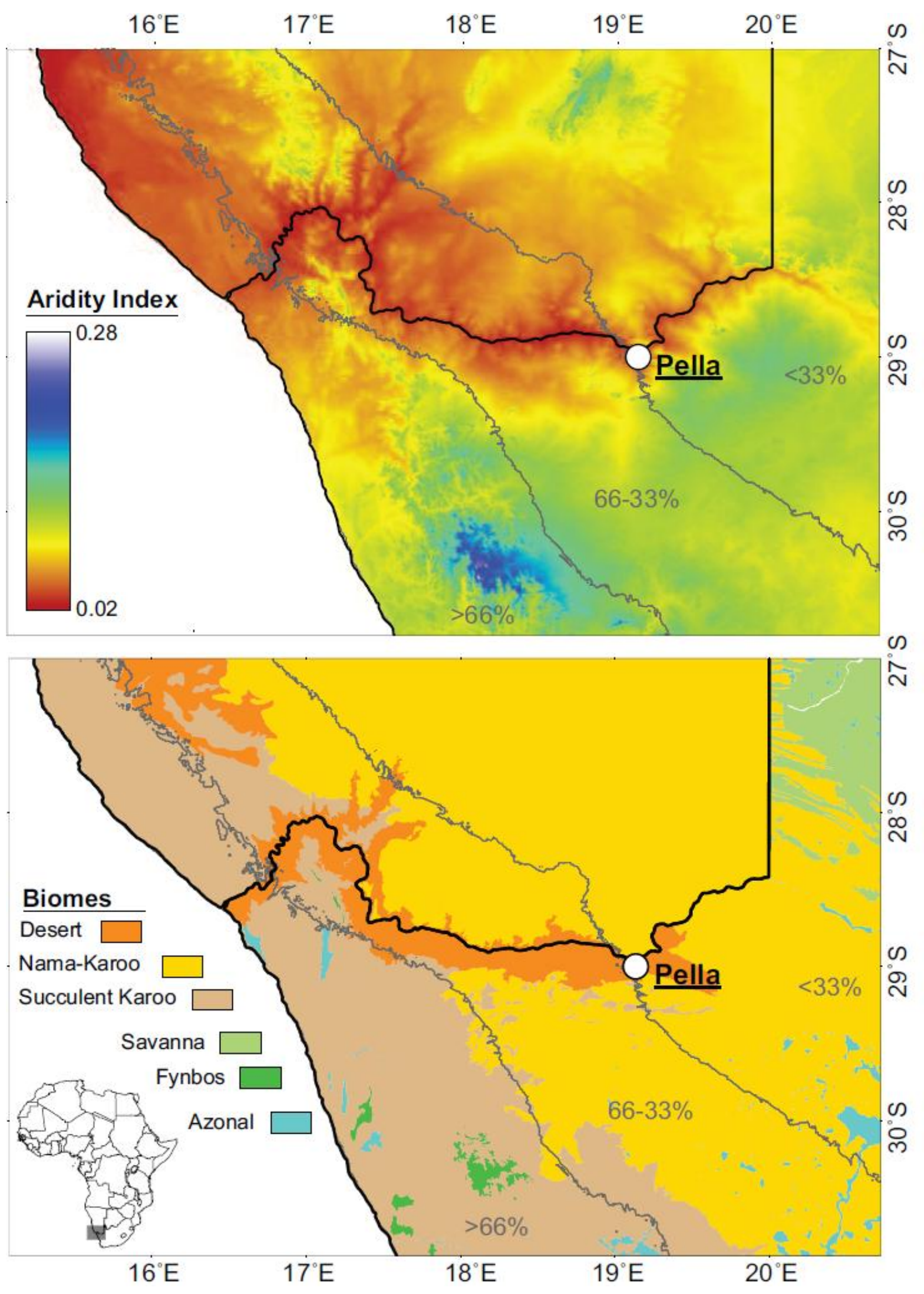

Fig. 1 


\section{ACCEPTED MANUSCRIPT}
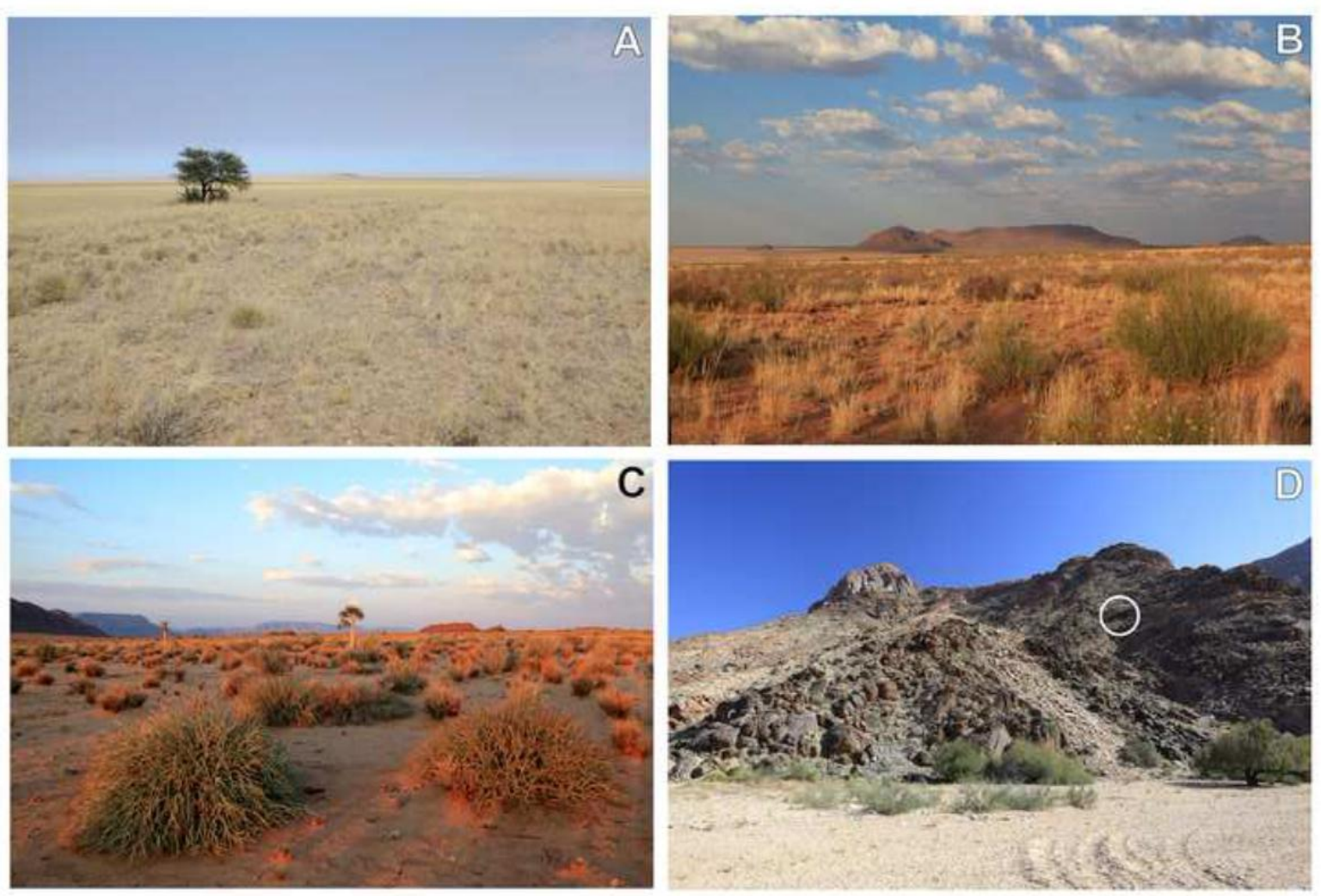

Fig. 2

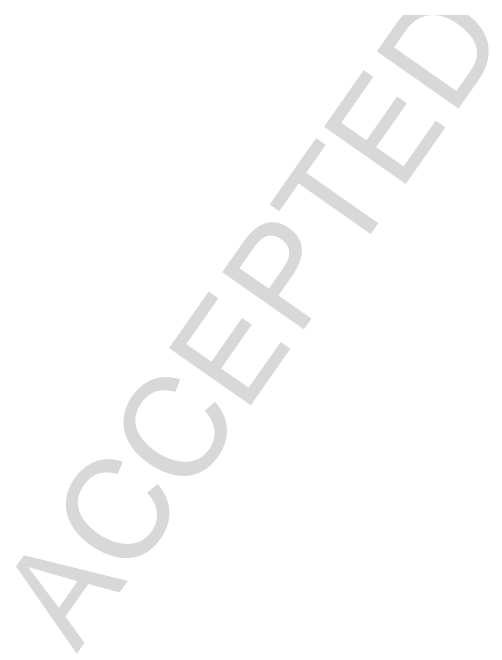



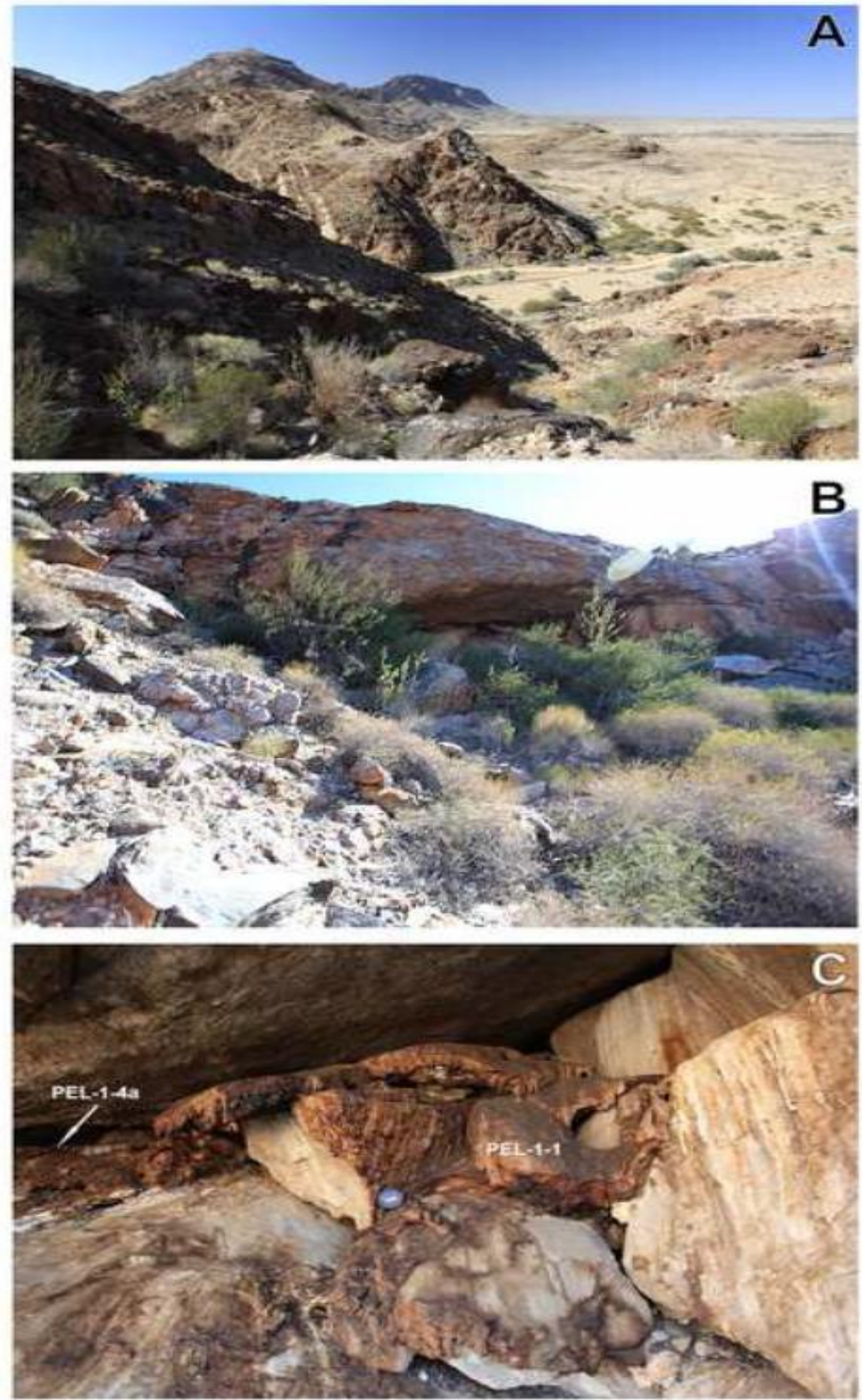

Fig. 3 

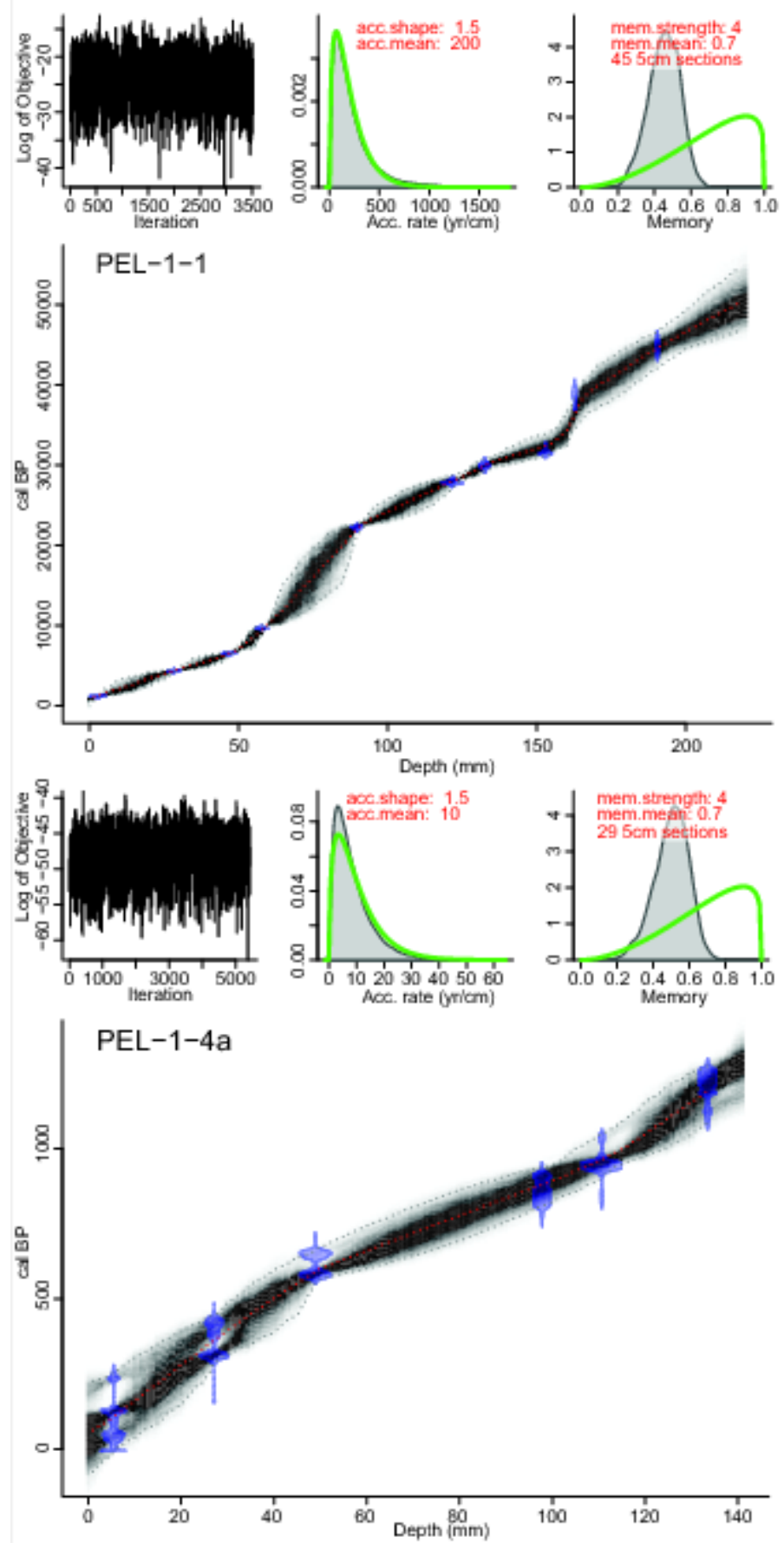

Fig. 4 


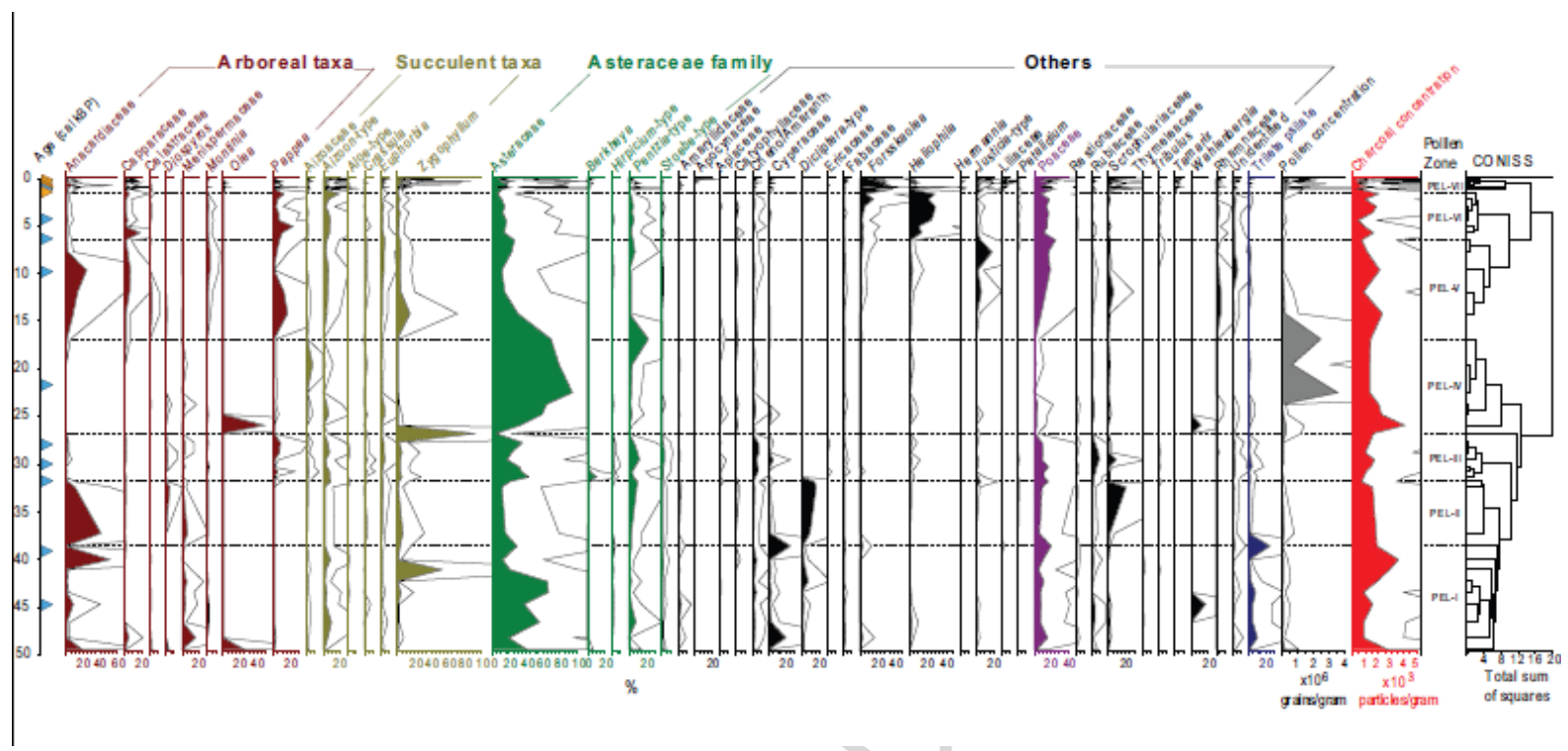

Fig. 5 


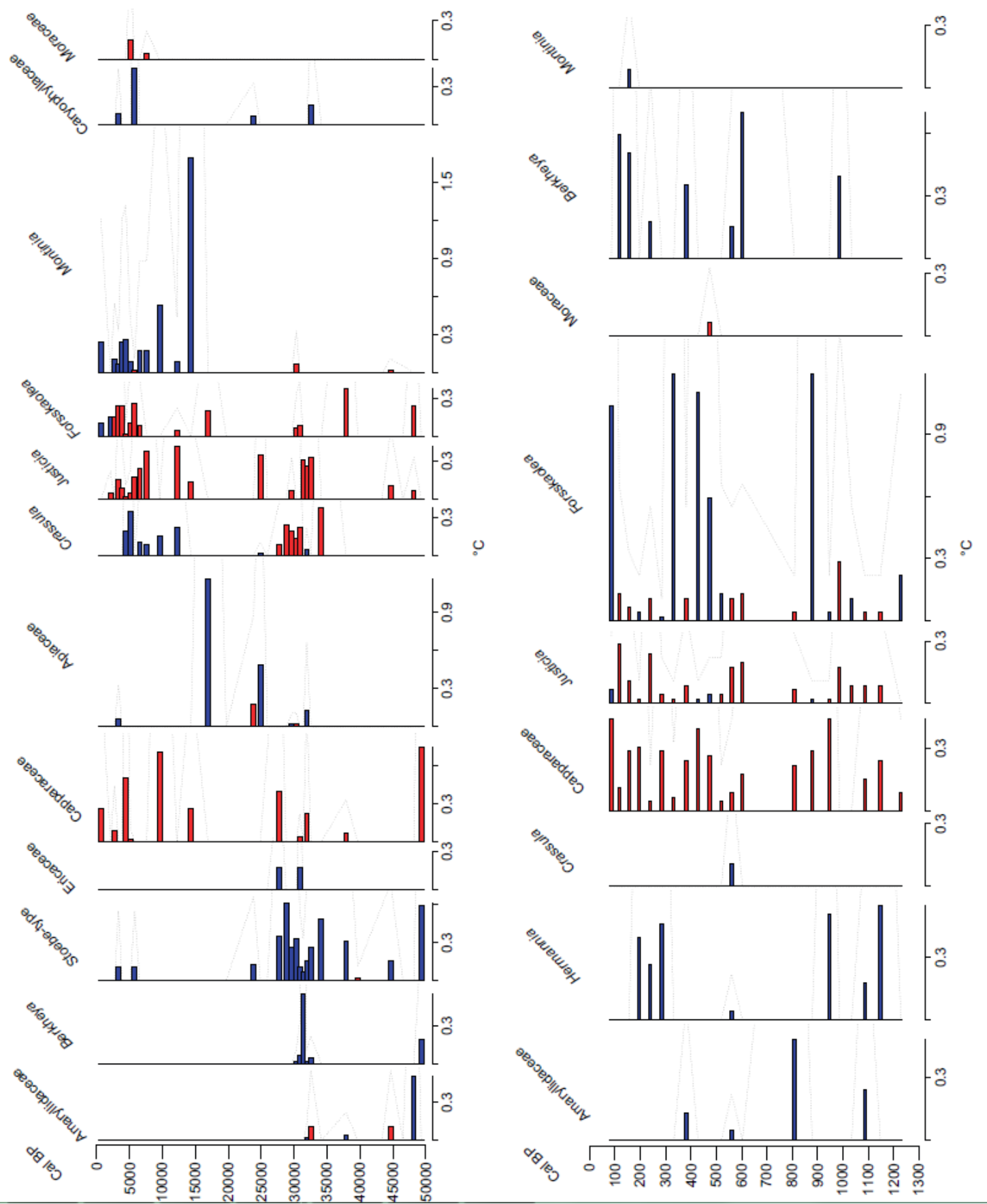

Fig. 6 


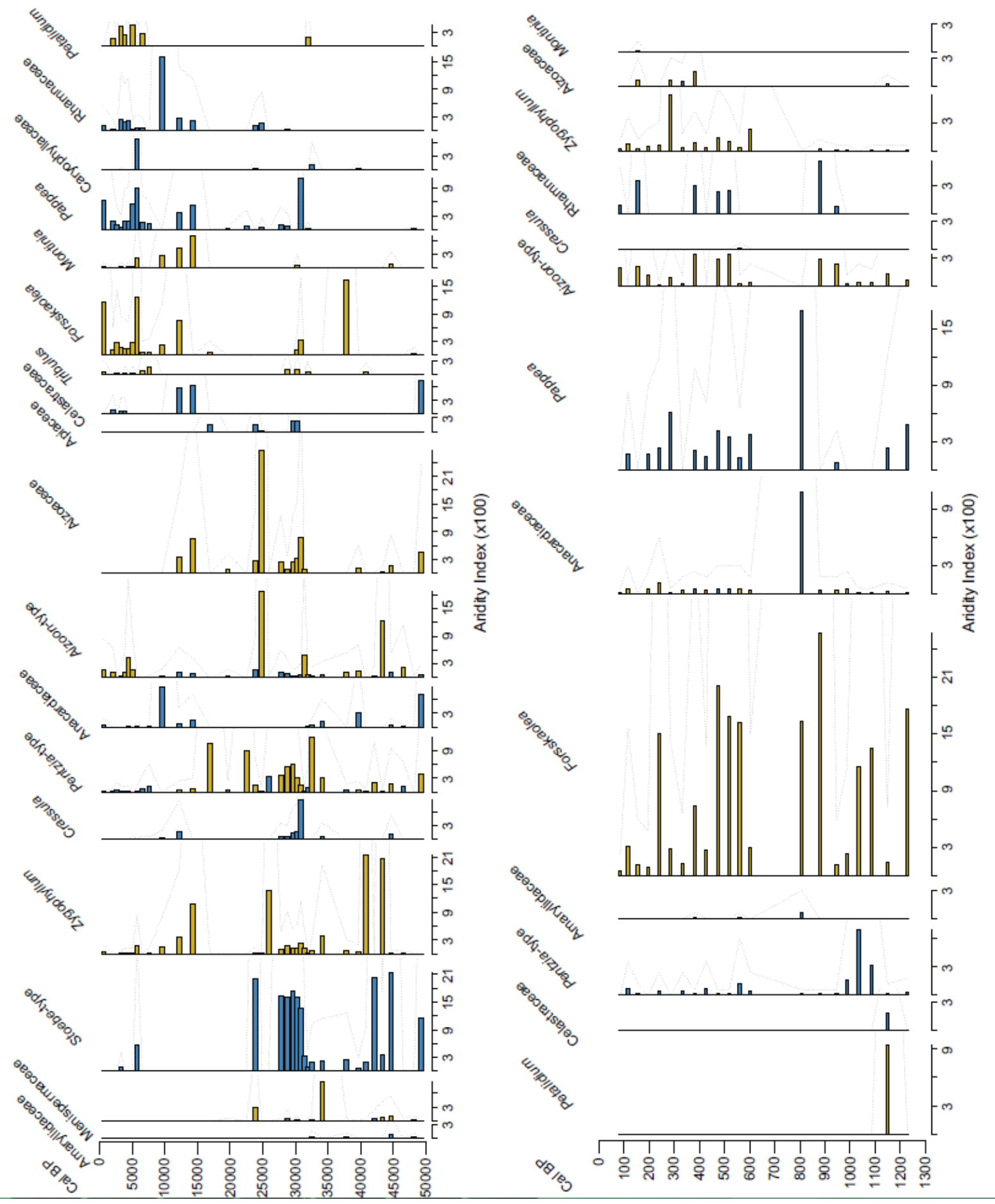

Fig. 7 

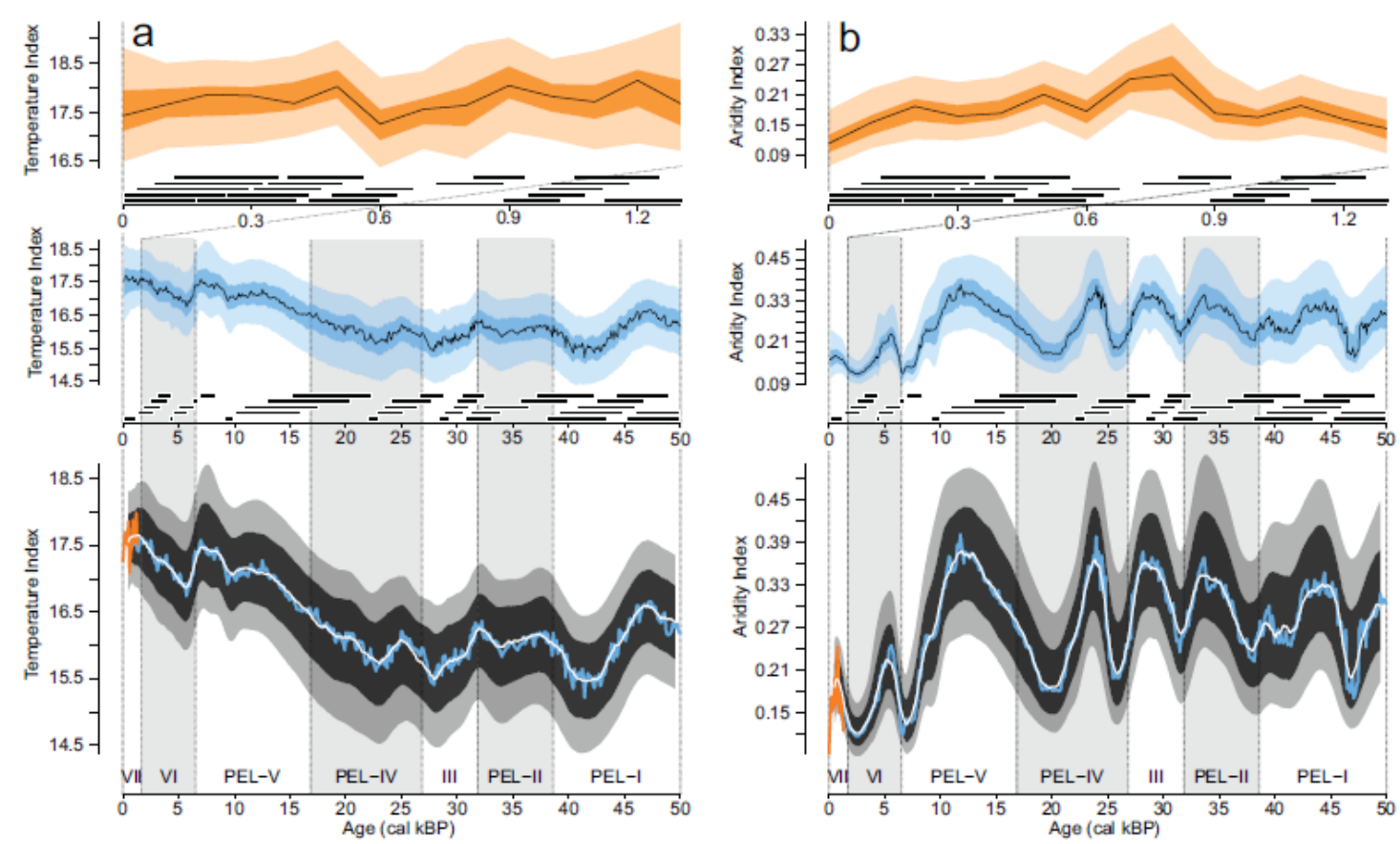

Fig. 8 


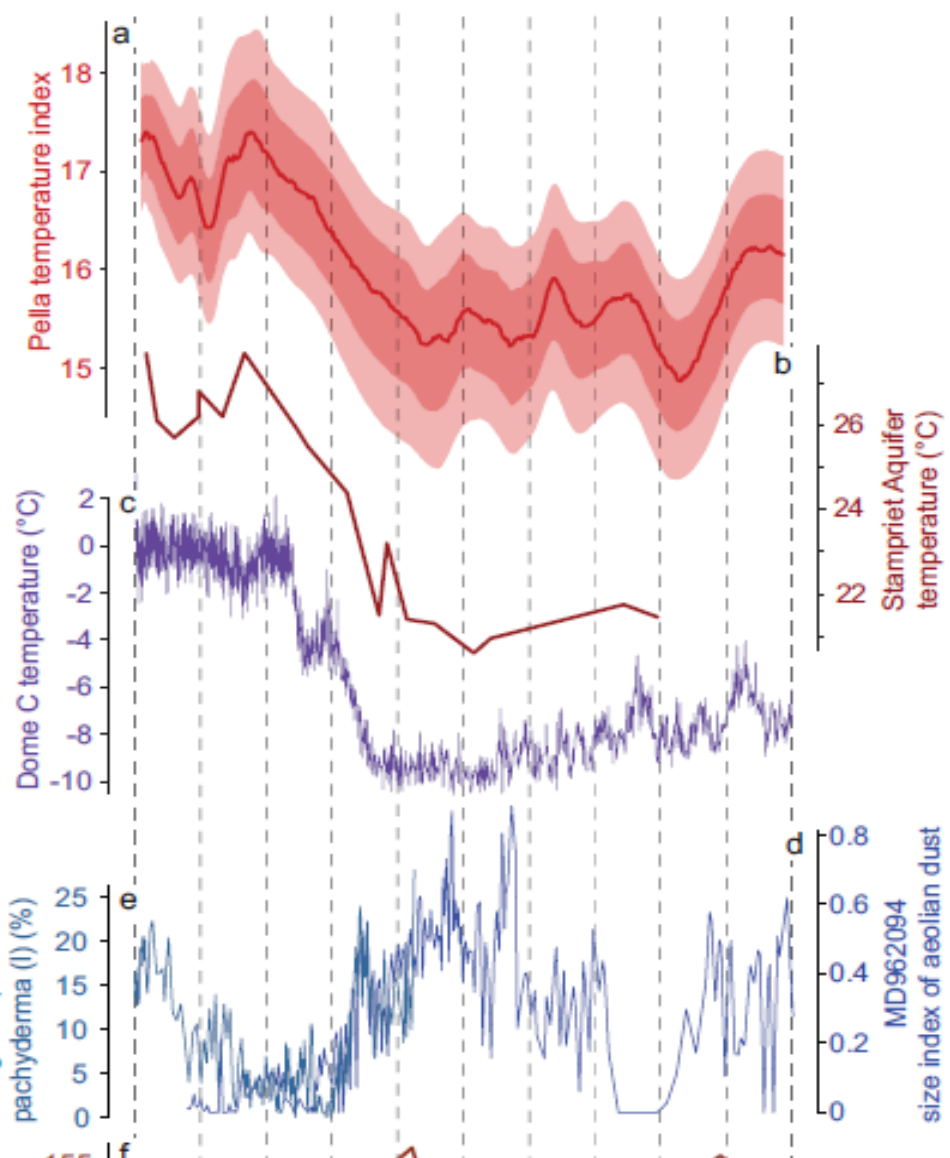

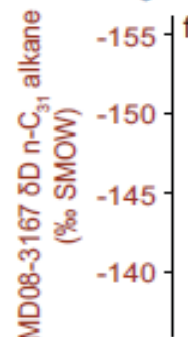

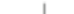




\section{HIGHLIGHTS}

- First continuous pollen record from southern Namib Desert spanning last 50 kyr.

- Last glacial period characterised by increased water availability relative to Holocene.

- Changes in potential evapotranspiration identified as important driver of humidity variability.

- Expansion of Desert Biome with increased Holocene temperatures.

- Consistently low Restionaceae pollen abundance indicates no significant expansion of Fynbos Biome during last 50 kyr. 